\title{
SOME EFFECTS OF EXTERNAL CONDITIONS UPON THE WHITE MOUSE
}

\author{
BY
}

FRANCIS B. SUMNER

With Fourteen Figures

The production of definite modifications in the structure, color or size of animals or plants by artificial changes in the conditions of life has been successfully accomplished over and over again by a large number of investigators. I need only allude to such classical instances as the experiments of Dorfmeister, Weismann and others on butterflies, Schmankewitsch on Artemia, Cunningham on flounders, Naegeli and Bonnier on Alpine plants, or to the more recent work of Tower ${ }^{1}$ upon beetles and Beebe ${ }^{2}$ upon birds. The fact that such considerable modifications may be produced within the lifetime of an individual by physical or chemical means is in itself interesting if regarded simply as an illustration of the plasticity displayed by many organisms. But when we push our inquiry beyond the merely descriptive plane, we are brought face to face with some of the most fundamental problems of biology. Are these modifications adaptive in their character? Do they in any instance correspond to the features which distinguish one natural species or geographical variety from one another? And finally, do such artificially produced modifications reappear in offspring which have not themselves been subjected to the conditions of the experiment? These are some of the questions which demand an answer from the investigator. They are not so simple and easy of solution as may appear on the surface: the first

\footnotetext{
${ }^{1}$ An Investigation of Evolution in Chrysomelid Beetles of the Genus Leptinotarsa. Carnegie Institution, 1906, pp. 320, pl. 30.

${ }^{2}$ Geographic Variations in Birds, with Special Reference to the Effects of Humidity. Zoölogica: N. Y. Zoöl. Soc., Sept. 25, 1907, pp. 4I, pl. 6.
} 
because we cannot always declare with confidence whether or not a given character is adaptive; the second, because the average experimentalist is as little conversant with the literature and methods of the systematist as the systematist is with those of the experimentalist; and the last, for reasons so numerous that they cannot even be outlined within the limits of the present paper.

Herein are presented some of the results of an inquiry into the effects of differences of temperature and humidity upon the postnatal development of the white mouse. ${ }^{3}$ In all, upwards of 400 individuals have been subjected to the experimental conditions during the past three winters, ${ }^{4}$ though it must be confessed that the number of mice in any one series has been relatively small. Due allowance has been made for this fact, however, in considering the probability of the various conclusions which are offered below. As will later be pointed out, differences which are great enough and constant enough are to be regarded as significant, even though the number of individuals is small. And it is scarcely necessary to remind my readers that the statistical treatment of even such small numbers as are here under discussion requires a great amount of extremely tedious work.

It must be acknowledged at once that $I$ have been actuated by ulterior motives in pursuing these experiments. My primary object has been to test the question of the transmission of certain characters, or, more correctly, of their reappearance in the offspring. Thus far, it is true, no satisfactory or at all convincing test of this point has been made by the writer, though the experiments are still far from being ended. Large, obvious, and readily measurable changes have, however, been produced in the generations immediately subjected to the conditions employed. Thus one of the primary requirements for the fulfilment of such a test has been realized. It is not the purpose of this paper, accordingly, to present any evidence in favor of transmission. I shall content

\footnotetext{
3 Some of the earlier results of this work were presented briefly before the American Society of Zoölogists, New Haven, December, 1907 (abstracted in Science, March 20, 1908.

1 To this number must be added nearly 300 others, the data for which were not available when the present pajer was being prepared. A brief mention of this most recent series has, however, been inserted on a later page.
} 
myself with recounting some of the modifications produced during the lifetime of the individual.

\section{ENVIRONMENTAL CONDITIONS}

Early in life, in each experiment, the mice were divided into two lots, one of which was transferred to a room artificially heated, ${ }^{5}$ the other to a room readily accessible to the winter atmosphere. The source of heat employed was a large steam coil which was ordinarily very effective. The room used throughout most of the work was, however, extremely pervious to draughts of air, and a strong wind from the proper quarter would sometimes bring down the temperature as much as 5 or $10^{\circ} \mathrm{C}$. in the course of an hour or two. In the fall and early part of the winter, the steam was available during the daytime only; commencing about January $\mathrm{I}$, it was turned on night and day. The cold room used in the two earlier series of experiments was situated in another part of the same building as the warm one. During much of the time a window was kept open in the former, though this was not necessary when the wind blew from the right direction, at which times the temperature would fall nearly to that of the atmosphere outside. An unfavorable wind, on the contrary, frequently forced in warm air from other parts of the building. Thus in the case of neither of these rooms did conditions favor the maintenance of a very uniform temperature, and at times the fluctuations were rather violent. ${ }^{\circ}$ Nevertheless the mean temperature throughout the experiments was very much higher in one room than in the other (Fig. I), and the fluctuations resulted in little if any harm to the animals. Necessarily the humidity likewise differed to an enormous degree. In the cold room, the air was frequently near the saturation point. In the warm room, on the contrary, this

\footnotetext{
${ }^{5}$ Certain rooms in the U. S. Fisheries Laboratory at Woods Hole, Mass., not otherwise in demand during the winter months, were employed for this purpose. The material equipment has been provided almost wholly by the author himself. I must except a considerable number of cages kindly lent by Professor Morgan during the third winter of the work.

'During the present winter my facilities have been much better. Through the kindness of the director, Dr. F. R. Lillie, I have had the privilege of locating my cold room in a small unheated building belonging to the Marine Biological Laboratory. Here, therefore, the only fluctuations are those due to changes of weather.
} 
same air, being heated to a temperature of $20^{\circ}$ or $30^{\circ} \mathrm{C}$., its humidity (degree of saturation) fell to $5^{\circ}$ per cent or even considerably less. There is a popular fallacy to the effect that moist air may be dried by heating, after the manner of one's damp clothes. The notion contains this element of truth, of course - namely that heating, except when the same degree of saturation is maintained by evaporation, does increase the capacity of the air for taking up moisture from other objects. Accordingly, in the present experiments, the sawdust upon the floor of the cages and the cotton waste used for bedding were much damper in the cold room than in the warm one. Indeed there was commonly no perceptible dampness at all in the latter, while in the former it became distinctly moist if the changing were long neglected. The relative humidity was determined at rather irregular intervals by the use of an ordinary psychrometer or wet-and-dry-bulb thermometer. The percentage values were obtained from the scale attached to the "hygrophant," manufactured by J. S. F. Huddleston of Boston, though the instrument actually used was a similar one of another make. These percentages are probably to be regarded as rather rough approximations. They are, however, believed to suffice for present purposes. The temperature, in each room, was recorded continually by means of a thermograph, and thus the daily and hourly fluctuations of temperature could be followed. ${ }^{7}$

Since the conditions and methods of treatment differed considerably in the different series of experiments, a further account of these is deferred to the separate discussions of the latter. No account of the feeding nor of the general care of the mice is regarded as necessary here. ${ }^{8}$ It is sufficient to state that, except for the differences in temperature and humidity above mentioned, it was my endeavor to maintain all conditions as similar as possible for the two contrasted lots of animals.

\footnotetext{
'The laborious task of computing the mean temperatures, etc., from the tracings upon the thermograph sheets has been mainly performed by my wife and my mother.

${ }^{8}$ I must acknowledge my indebtedness to Prof. W. F. Castle and Prof. T. H. Morgan for valuable suggestions relative to the care of the mice. The stock was all obtained from Miss Abbie E. C. Lathrop, the well-known animal breeder, of Granby, Mass.
} 
In the selection of these characters it was of course desirable to choose one or more which might be supposed to be influenced adaptively under the conditions of the experiment. Quantity of hair was therefore chosen as one of the values to be determined. Theoretically the hair might be subjected to quantitative treatment in three different ways: ( $\mathrm{I}$ ) by determining the average length of the hairs on each pelt, based upon a considerable number of individual hairs, so taken as to be representative of the entire lot;(2) by finding the number of hairs on a given unit of skin area; (3) by ascertaining the weight of the entire pelage or hair-coat of each mouse. The first method was very soon found to be impracticable; owing to the fact that the hairs are seldom straight enough for the purpose, being commonly curved or zigzag. The second and later the third methods were, however, employed more or less advantageously. For the determination of the number of hairs in a given unit of skin, the latter, immediately after removal from the freshly killed animal, was subjected to a stretching process which was as far as possible identical for each pelt. Pinch clamps were fastened at six points on the margin of the skin, and to these were attached fine cords which passed outward over pulleys arranged around the skin in a circle. Each cord bore a roo-gram weight. The pelt was thus gently stretched for five minutes, after which a large cork was pressed lightly against its central region, and the skin pinned to it by a circle of 16 pins. The outlying portions of the pelt were now cut away, and the circular area which was left pinned to the cork was allowed to dry. After a variable interval, depending on convenience, a small disk of the skin was cut out by means of a tool devised for the purpose. This consisted of a steel tube, $\mathrm{I} \frac{1}{2} \mathrm{~mm}$. in diameter, sharpened at one end into an edge. In use, it was pressed rather lightly against the inner surface of the skin and rotated until the latter was completely cut through. The resulting disk of skin was fastened to a black tile - hair uppermost, of course-by means of glue. The hairs were now shaved off with a sharp knife and counted under a low power lens. Two disks from symmetrically placed points on the pelt 
of each mouse were used, and it was sought to take them from corresponding regions of the skin in the case of every animal. The entire process required much time, and the counting of the hairs proved to be extremely fatiguing to the eyes. Moreover the great individual differences in the density of the hair and even the differences in density on the two sides of the same individual showed that satisfactory figures could not be obtained without making a large number of determinations. For these and for other reasons the counting of hairs was abandoned after the first year's series of experiments. The results, so far as obtained, will be presented later in the paper.

The method of weighing the total pelage of each mouse has proved to be by far the most satisfactory one. Aside from the greater ease and accuracy of technique, this method has the advantage of showing whether or not the total quantity of hair has varied under the different conditions. It has the disadvantage, however, of not showing how the quantity has been affected, i. e., whether by the augmentation of the number of developed hairs, or of their length or their diameter. The process employed was as follows: ${ }^{9}$ The pelt after drying was placed in a saturated solution of calcium hydrate, and left for three days (occasionally longer) ${ }^{10}$ After rinsing, the hair was scraped off with a moderately sharp scalpel. Most of the hair, in the majority of pelts, could be removed very readily; the remainder sometimes required considerable scraping. The epidermal cells were unavoidably scraped off at the same time, but these furnished very little material, and that was for the most part removed by washing. In any case their presence constituted a source of error which was probably practically constant throughout the series. The hair, after a thorough washing in water, was treated for ten to twenty minutes with dilute $\mathrm{HCl}$ ( 5 per cent) in order to remove any calcium which might remain in association with it. After further repeated washings, it was dehydrated in 95 per cent alcohol, subjected to ether for one hour,

\footnotetext{
-Acknowledgment is due to Dr. C. L. Alsberg, of the Bureau of Plant Industry, for valuable suggestions relating to certain steps in this process.

${ }^{10}$ An equal number of skins of the two lots were always treated at the same time, so that constant differences in treatment were avoided.
} 
to insure the removal of fats, and then dried in the air. Each lot (the total pelage derived from a single pelt) was now put into a weighing bottle and transferred to a vacuum desiccator, until the weight was found to have become constant (usually for about four days). The final weight was recorded to the ten-thousandth of a gram, though only thousandths have been regarded in the present paper. Since a number of specimens were dealt with at once, the process did not require as much time as might be inferred from the number of steps involved. The results obtained are presented below (pp. I29-I3I).

Other characters chosen for measurement were: weight, length of body (from snout to anus), length of tail (from anus to tip), length of left ear (from the lower extremity of the incisura intertragica ${ }^{11}$ to the tip of the pinna), and length of left hind foot (from heel to tip of longest toe). Certain additional determinations, which were made in special cases, will be referred to at the proper time. A uniform method of procedure was adopted in making each of these measurements. In order that my figures may be of service for comparison with those of other workers in this field, it seems desirable to detail these methods a little more fully. The weight was taken by means of a torsion balance sensitive to a few hundredths of a gram. The tail length was obtained in two ways, according to whether the animal was living or dead when measured. When measured living, the mouse was suspended by the tip of the tail, the forefeet being allowed to rest upon the table. A certain degree of stretching generally occurred, the amount of which was found to average somewhat over $2 \mathrm{~mm}$. in the case of full-grown mice. Weight and tail length were the only characters which it was possible to determine accurately with living animals. ${ }^{12}$ In measuring the tail of the dead mouse, and likewise the body length, the freshly killed animal was laid with the ventral surface uppermost upon a wooden board. A pin was passed through the roof of the mouth, thus securing the snout to the board. The latter was then held upright and the body allowed to dangle

\footnotetext{
${ }^{11}$ Or at least a point which would seem to be homologous with the part so named in the human ear.

${ }^{12}$ I have since found it practicable to measure the ear and foot, in the living mouse, by the use of ether (April, 1909.)
} 
for a few seconds, after which a second pin was passed through the basal part of the tail, which was thus likewise fastened securely in place. The distance from the tip of the snout to the anus and that from the latter to the tip of the straightened tail (exclusive of terminal hairs) were found by means of a graduated sliding caliper provided with a vernier. When the ear length was taken the mouse was laid freely upon the right side. In measuring the length of the right hind foot, the animal's body was held in the left hand, the sole of its foot pressed lightly against the board, and a pin passed through the instep into the wood. The tarsal joint was bent at about right angles, and the heel allowed to rise above the surface of support as in life. The caliper spanned the distance from the tip of the heel, which was touched rather lightly, to the tip of the nail of the middle (third) toe. It was found important to make all of these measurements as soon after death as possible. In the later series, two determinations were made of each part measured, and the reading was taken in tenths of a millimeter.

Throughout the whole of this work, the practice was followed, so far as possible, of measuring warm-room and cold-room individuals alternately, or at least of alternating small groups of individuals. Only thus would such gradual changes in one's standards of judgment as would inevitably result from growing experience, affect equally the two groups to be compared.

The characters selected are few in number, we must allow, and are, for the most part, such as would not be expected to respond adaptively to the treatment accorded to the animals. One must, however, accept the limits imposed by brevity of time and the nature of the material at hand. When subjected to statistical treatment a very few characters are found to involve a very great amount of labor. Moreover, aside from thickness of fur, such adaptations as might be conceived of as resulting from temperature conditions would probably be histological or chemical in their nature and therefore not accessible to ready methods of quantitative treatment.

The measurements which I have chosen as being applicable to these mice are, with the exception of those relating to the hair, 
ones which are employed by mammalologists who concern themselves with rodents. Coues and Allen, ${ }^{13}$ for example, give the following external measurements for Muridæ, Leporidæ, Sciuridæ, etc.: From tip of nose to (I) eye, (2) ear, (3) occiput, (4) tail; length of tail to end of (1) vertebræ, (2) hairs; length of fore-foot, and hind foot "from the tuberosity of the heel to the end of the longest claw"; height of ear. Merriam, ${ }^{14}$ likewise, presents figures for "total length" (i. e., body plus tail); "tail vertebra" (i. e., length of the vertebral portion of the tail); "pencil" (tuft of hair at tip of tail); "hind foot;" "ear from crown" (sometimes from "anterior root" or from "notch"); and occasionally some others, including weight. Various dental and skeletal features are of course included in the complete diagnosis of a species, as well as differences in the color, texture and length of the pelage. But many of these characters are such as do not lend themselves to measurement, while others require the preparation of cleaned skeletons.

\section{STATISTICAL METHODS}

Since it is to be presumed that many biologists are still unfamiliar with the methods of biometry, the following statement as to those employed in the present paper may not be out of place. ${ }^{15}$ For a really earnest and, on the whole, successful endeavor to render this difficult subject intelligible to the non-mathematical mind, the reader is referred to Thorndike's "Introduction to the Theory of Mental and Social Measurements" (Science Press, 1904). Davenport's "Statistical Methods" is of course indispensable to those who are already sufficiently familiar with the use of these methods.

The mean or average of a series of values (in the present case,

13 Monographs of North American Rodentia. Report of the U. S. Geological Survey, vol. xi, I877, pp. I-rog1.

14 "North American Fauna" series, published by the Biological Survey of the Department of Agriculture.

${ }^{15}$ My thanks are due to Messrs. E. L. Thorndike and R. P. Bigelow for criticising certain portions of my manuscript and to Prof. C. B. Davenport for important information relative to biometrical methods. 
measurements) is obtained by dividing the sum of all the terms of the series by the number of these terms.

The standard deviation, which is, at present, most frequently employed as the measure of the variability of a series, is obtained by squaring all the individual "deviations" or departures from the mean, finding the sum, and then the average, of these squared deviations, and extracting the square root of the resulting average, i. e.,

$$
\sqrt{\frac{\text { sum of squared deviations }}{\text { number }}}
$$

The reliability of the average or mean has, in each case, been indicated by the probable error, which is the number preceded by the \pm sign and annexed to the mean in the following tables. The value of this number is such that there is an even chance that the true mean (i. e., such as would be obtained from averaging an infinite number of terms) lies within the limits indicated by: given mean \pm probable error. The probable error of an average or mean is obtained by the formula

$$
\frac{.6745 \times \text { standard deviation }}{\sqrt{\text { number of terms in the series }}}
$$

The reliability of an average thus varies inversely as the variability of the series and directly as the square root of the number of terms. The probable error of the mean, here employed as an index of reliability, is not to be confused with the probable error of a series, sometimes employed as an index of its variability. This latter is a number of such magnitude that it is exceeded by exactly one-half of the deviations. It has the value: $.6745 \times$ standard deviation.

The reliability of the standard deviation, or figure denoting the variability of each series, is indicated by the probable error of the standard deviation. This is obtained by the formula:

$$
\frac{.6745 \times \text { standard deviation }}{\sqrt{2 \times \text { number of terms }}}
$$


Since one of the primary objects of such investigations as the present is an inquiry into the effects of differences in the conditions of life upon supposedly homogeneous material, one of the principal points to be determined is the significance of any differences which may be discovered between the average values of a given character in two groups of individuals whose history has differed. For this purpose it is necessary to compare the probable error of the difference with the actually obtained difference between the two averages in question. The probable error of the difference is expressed by the formula:

$\sqrt{{\text { (probable error of the first average })^{2}}^{2}(\text { probable error of the second average })^{2}}$

i. e, the square root of the sum of the squares of the probable errors of the two respective averages. Now the actually obtained difference is the most probably true difference and it is as likely to be too small as too large. Nevertheless the true difference may possibly equal $o$, i. e., be non-existent, in which case the obtained difference would be regarded as wholly "accidental." From the table of the values of the "probability integral" it may be calculated that the chances that a difference between two averages is due to mere accident are:

250 out of 1000 when difference between averages $=1 \times$ probable error of the difference.

I56 out of 1000 when difference between averages $=1.5 \times$ probable error of the difference.

89 out of 1000 when difference between averages $=2 \times$ probable error of the difference.

46 out of 1000 when difference between averages $=2.5 \times$ probable error of the difference.

21 out of 1000 when difference between averages $=3 \times$ probable error of the difference.

9 out of 1000 when difference between averages $=3.5 \times$ probable error of the difference.

3 out of 1000 when difference between averages $=4 \times$ probable error of the difference. less

than
I out of 1000 when difference between averages $=4.5 \times$ probable error of the difference,

In proportion as the probability decreases that such a difference thas been due to mere chance or accident (i. e., that it is the result of a multitude of independent causes having no relation to the conditions of the experiment), it is obvious that the probability increases that some constant modifiying influence has been operative in differentiating the two groups. It must be admitted however, that the probabilities here stated apply in full strictness 
only to cases where we are dealing with large numbers of individuals. Davenport suggests 200 as the minimum number of individuals to be gathered for statistical treatment when the material is available; though he grants that much smaller numbers may be employed to advantage, where we are restricted by circumstances. But it must be borne in mind, he says" "that the rules for determination of averages, probable errors, standard deviations and all the rest become less and less significant as the number of variants becomes smaller. Finally, in the region of twenty or so, the results can no longer be treated by mass statistics; twenty hardly makes a mass." To the experimentalist it must often happen, as in the present work, that the use of a large number of individuals, in any single series, is excluded by reason of the laboriousness of the methods employed. In such cases, we are told, no exact mathematical equivalent can be offered for the probability of a given result, even though the frequency distributions afford strong evidence on the subject. Or course the cumulative testimony of several independent series of experiments is of high value. In general, it would seem that the experimentalist demands a somewhat different statistical technique from the student of variation per se, and it is to be regarded as unfortunate that the methods at our disposal, have, thus far been developed mainly by the latter type of investigator, and with very little reference to the special needs of the former. To the experimentalist, who is studying the effects of artificial conditions, it is the significance of differences, and scarcely anythingelse in the whole field of statistical theory, that is likely to be of interest.

Regarding the accuracy of my computations, I can only say that every step has been gone over at least twice, and that, wherever possible, a different method of calculation has been employed in the repetition.

$$
\begin{aligned}
& \text { RESULTS IN DETAIL } \\
& \text { Series of } 1906-1907
\end{aligned}
$$

Owing to the small number of individuals used and the tentative character of my methods at the outset, this first series will not be

${ }^{10}$ In a letter to the author 
discussed at all fully. The mean temperatures in the two rooms, during the period of the experiment, were $24.9^{\circ} \mathrm{C}$. and $9.1^{\circ} \mathrm{C}$. $\left(76.8^{\circ} \mathrm{F}\right.$. and $48.4^{\circ} \mathrm{F}$.) respectively. No further analysis of the temperature conditions seems worth while in the present experiment. The humidity was not at any time determined. Twentyone mice ( 13 males and 8 females) were reared in the cold room; 20 mice (12 males and 8 females) in the warm room. The animals were not subjected to the differing temperatures until they were about three weeks old $(2 \mathrm{I} \pm$ days $)$. Previous to that time, the undivided lots had been reared under similar conditions. Each lot comprised individuals from 7 different broods, each of the latter having been divided into two portions destined for the warm and cold rooms respectively. About half the stock, consisting of the broods earliest obtained, were subjected to the experimental conditions for a period of 106 days, the remainder for a period of 83 days. At the expiration of these terms the mice were paired for breeding purposes, and the two contrasted lots were transferred to a single room having a temperature somewhat intermediate between those previously employed. None of the animals were killed immediately after this transfer, while the females were kept until they had reared their broods. The interval between the discontinuance of the temperature differences and the killing of the animals varied from 15 to 55 days. Thus the material was far from homogeneous. Nevertheless the figures obtained seem worth recording. (Table $\mathrm{I}$.) ${ }^{17}$

The difference in tail length, in the males, at least, was often obvious without measurement, and it must be regarded as a significant one, even without such overwhelming corroborative evidence as is offered later. In the case of the females, the difference is much smaller, though it is greatly in excess of the probable errors. No further analysis of this table seems called for.

In the present series, the number of hairs per unit of skin area was computed for each mouse, according to the method described

\footnotetext{
${ }^{7}$ Here and elsewhere the number of individuals measured for any given character is indicated by the figure in parentheses at the head of each column. In some cases individual tail measurements have been thrown out, where the tip of the organ had obviously been lost through accident. I trust, however, that it is not necessary to urge that no merely "exceptional" figures have been rejected
} 
TABLE 2

Series of 1906-1907: Numbe- of hairs per unit of skin surface

\begin{tabular}{|c|c|c|c|c|}
\hline & \multicolumn{2}{|c|}{ MALES } & \multicolumn{2}{|c|}{ FEMALES } \\
\hline & Warm (12) & Cold (13) & Warm (8) & Cold (8) \\
\hline & $\left.\begin{array}{l}\left.\begin{array}{r}165 \\
132\end{array}\right\} 297 \\
\left.\begin{array}{l}164 \\
137\end{array}\right\} 201 \\
\left.\begin{array}{l}138 \\
135\end{array}\right\} 273 \\
\left.\begin{array}{l}113 \\
137\end{array}\right\} 250 \\
\left.\begin{array}{l}95 \\
110\end{array}\right\} 205 \\
\left.\begin{array}{l}157 \\
123\end{array}\right\} 280 \\
\left.\begin{array}{l}128 \\
97\end{array}\right\} 225 \\
\left.\begin{array}{l}137 \\
137 \\
130\end{array}\right\} 267 \\
\left.\begin{array}{l}135 \\
154\end{array}\right\} 266 \\
123\end{array}\right\} 232$ & 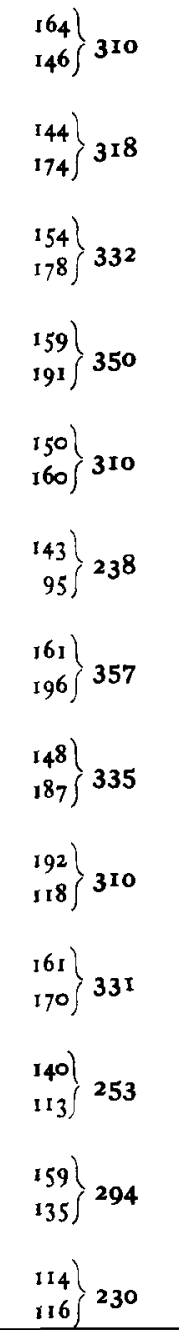 & $\left.\begin{array}{l}\left.\begin{array}{l}190\} \\
204\end{array}\right\} 394 \\
\left.\begin{array}{l}140 \\
174\end{array}\right\} 314 \\
\left.\begin{array}{l}189 \\
149\end{array}\right\} 338 \\
164 \\
162\end{array}\right\} 326$ & $\begin{array}{l}\left.\begin{array}{l}242 \\
220\end{array}\right\} 462 \\
\left.\begin{array}{r}174 \\
182\end{array}\right\} 356 \\
\left.\begin{array}{l}165 \\
150\end{array}\right\} 315 \\
\left.\begin{array}{l}136 \\
159\end{array}\right\} 295 \\
\left.\begin{array}{l}127 \\
136\end{array}\right\} 263 \\
\left.\begin{array}{l}158 \\
147\end{array}\right\} 305 \\
\left.\begin{array}{l}152 \\
139\end{array}\right\} 291 \\
\left.\begin{array}{l}151 \\
159\end{array}\right\} 310\end{array}$ \\
\hline Mean $\ldots \ldots \ldots \ldots \ldots$ & $267.08 \pm 6.12$ & $305.23 \pm 7.37$ & $320.87 \pm 11.96$ & $324.62 \pm 13.68$ \\
\hline Standard deviation...... & $3^{1} \cdot 37 \pm 4 \cdot 3^{2}$ & $39.43 \pm 5.22$ & $50.12 \pm 8.45$ & $57.40 \pm 9.67$ \\
\hline
\end{tabular}


above (p. IOI). It seems worth while to present the individual figures obtained for these animals, since this is the only series with which the counting method was employed. In Table 2 each figure in the left-hand columns represents the number of hairs on a circular disk of skin $1.5 \mathrm{~mm}$. in diameter. Two figures are given for each individual, based upon two disks of skin taken at a distance of I $\mathrm{cm}$. to the right and the left respectively of the middorsal line. The sum of these two is stated in heavy type.

It will be noted that the mean number of hairs for the cold room males is 305.23 upon the two disks, that for the warm-room males being $267.08 .^{18}$ Here, then, is a difference of 14.3 per cent. The number of individuals is small, it is true, and the probable errors are large. Even granting the constancy, however, of such a difference, between two lots of mice thus treated, it is not necessary to conclude that there has been an actual increase in the number of (developed) hairs per unit of skin surface. If the warm-room individuals be supposed to have slightly thinner skins than those of the cold-room lot, the greater degree of stretching in the former (see p. IOI) would result in a less dense distribution of hair upon its surface. But whether a difference so produced would be as high as I4 per cent may well be questioned. Again, it must not be supposed that I am urging this difference in the density of the coat of hair as an instance of permanent morphological change. It may be due merely to a difference in the rate at which the hair is shed. This point will be discussed later.

The averages for the hairs of the female mice are not far from equal in the two contrasted lots. It has already been noted that the females exhibited a much smaller difference in tail length than did the males.

$$
\text { Series of } 1907-1908
$$

During the winter of $1907-1908$ the experiments were conducted on a much larger scale than previously, the conditions employed were such as were calculated to result in the production of greater

\footnotetext{
${ }^{18}$ The number of hairs per square millimeter of skin may be readily computed, since the area of each disk was (approrimately) $1.767 \mathrm{sq}$. $\mathrm{mm}$. Thus the mean number for the cold room males is 86.4 , that for all the mice comprised in the table is 85.0 , etc.
} 
modifications, and the number of measurements applied to the animals was considerably increased.

Temperature. The mean temperature ${ }^{10}$ of the warm room for the entire season was $26.30^{\circ} \mathrm{C}$. $\left(79.34^{\circ} \mathrm{F}\right.$ ), that for the cold room $6.16^{\circ} \mathrm{C}$. $\left(43.08^{\circ} \mathrm{F}\right.$.). These figures correspond roughly to those for the mean annual temperatures of Key West or Porto Rico, on the one hand, and those for Eastport, Maine, or Minneapolis, Minn., on the other. ${ }^{20}$ But it would not, of course, be at all fair to compare the temperature conditions of the experimental rooms with those of the points named, still less to compare the climatic conditions as a whole.

The mean daily range of temperature (i. e., mean difference between the maximum and minimum for each day) was II. $9^{\prime} \mathrm{C}$. $\left(21.4^{\circ} \mathrm{F}\right.$.) in the warm room, $6.7^{\circ} \mathrm{C}$. $\left(12^{\circ} \mathrm{F}\right.$.) in the cold room. The maximum temperature reached at any time in the warm room was about $40^{\circ} \mathrm{C}$. (for very brief periods), the minimum in the cold room being - $14 \cdot 4^{\circ}$. But these figures represent exceptional occurrences and have little significance. Curves have been constructed (Fig. I) showing the mean daily temperature in each room during the entire period of the experiment.

It is plain, of course, that none of these figures can represent the actual temperatures to which the mice themselves were most of the time exposed. When huddled together in large numbers in a nest of cotton-waste, the temperature of the air immediately in contact with them, at least in the case of the cold-room animals, was doubtless very much higher than that in the room outside, i. e., that recorded by the thermograph. Nevertheless, we all know by experience the difference between sleeping in a cold room and sleeping in a warm one, even when the amount of bedding is varied to suit the circumstances. And it must be remembered that during part of the time the mice were feeding, exploring the cages, etc., and were then wholly exposed to the air.

Humidity. The relative humidity in the warm room (see p. 100 above) ranged from about 22 per cent to about 66 per cent, the

${ }^{9}$ The mean temperatures here given are based upon four figures daily, these being taken from the thermograph sheets.

${ }^{20}$ Report U. S. Weather Bureau for 1906-1907. 
mean for 12 determinations made during a period of four months being 39 per cent. This is somewhat less than the mean relative humidity at Phoenix, Arizona, for the year 1906, as stated by the U. S. Weather Bureau, that point having the dryest atmosphere, with a single exception, of any place in the United States for which records are given. In general, the humidity of the warm room varied inversely as the temperature, since no compensation was made by the evaporation of water; but the degree of saturation of the outside air must have been a factor. The humidity of the cold room varied from about 49 per cent to about 90 per cent, the mean of nine determinations being 67 per cent. This figure is a trifle less than that given for the mean humidity of Philadelphia during the year 1906 .

The physiological results of such differences in humidity must be far reaching. The quality of the air inspired must affect the processes of respiration, and the rate of evaporation from the body surface must differ widely in the two cases. This last was shown by the eagerness for water displayed by the warm-room individuals. To what degree the results which I offer have been brought about by differences in temperature and to what degree by differences in humidity it is impossible to state. In these experiments it has not been practicable to control the humidity, independently of the temperature, and thus it has been impossible to decide this question definitely. The subject will be referred to later.

Disposition of Stock. Twenty broods of young mice, aggregating 135 individuals, were employed for this experiment. In order to insure, so far as possible, a division into two lots of a similar hereditary endowment, one-half the individuals of each litter were subjected to the high temperature, the other half to the low. For this purpose, exchanges were made between the offspring of different mothers according to the following plan: One-half of brood $A$, plus one-half of brood $B$, were consigned to the care of the $A$ mother in the cold room, the other half of each brood being consigned to the care of the B mother in the warm room, and so on through the series. This disposition of the young was made while the latter were 2 to 4 days old (in a few exceptional cases as much as I I days). The members of each litter were marked at the 


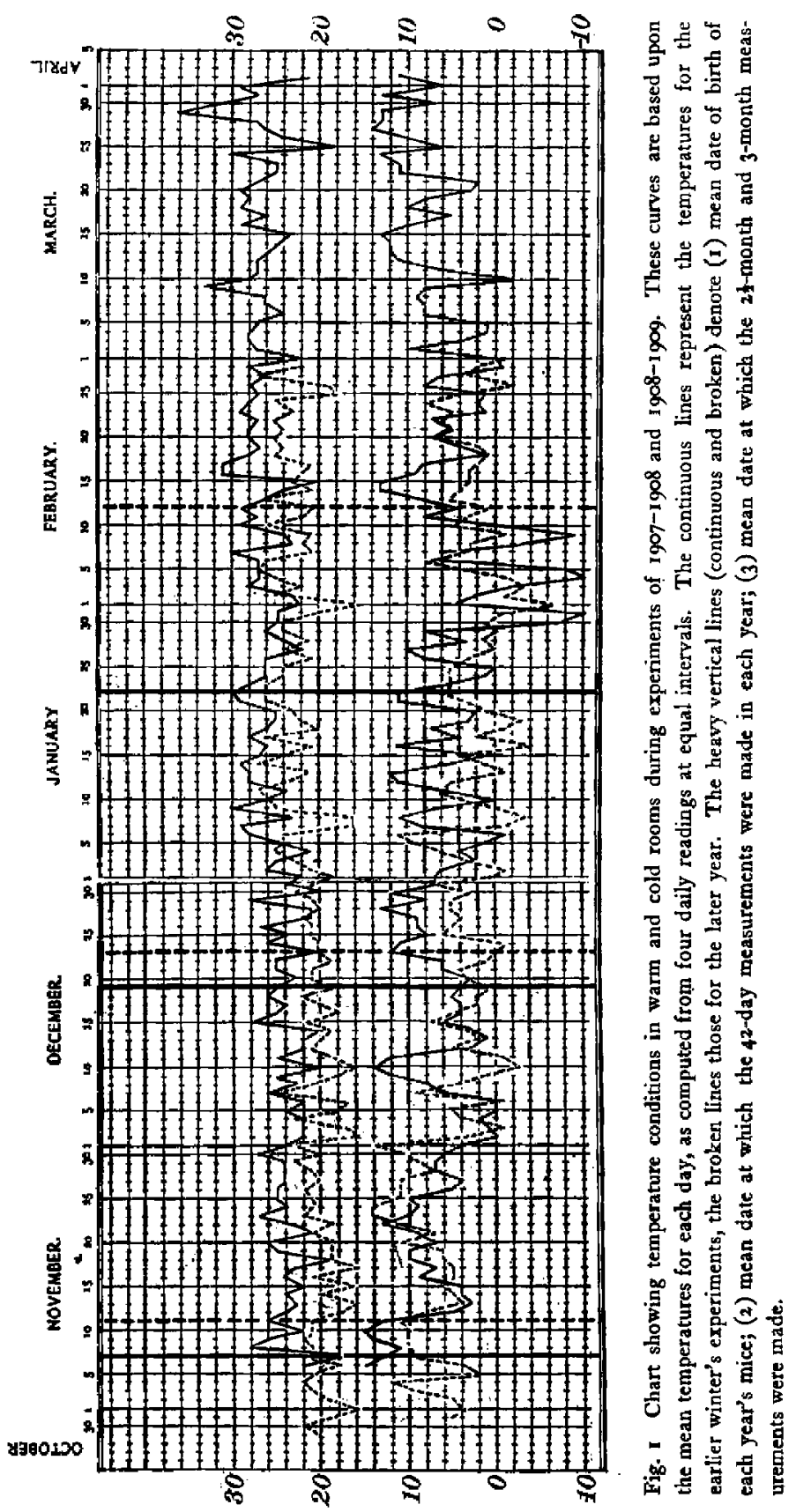


outset by a system of clipping the right ear and various fingers and toes of the right foot. Rather contrary to my expectations, the alien offspring were accepted by the mothers as readily as their own, so that little if any loss of life resulted from this procedure.

A certain proportion of deaths occurred here as always during the rearing of these mice. The number of deaths in the warm room during the first six weeks was 6 , giving a mortality of about 9 per cent. The number dying in the cold room was considerably greater, being I3, or about 20 per cent of the lot. During the next month of life no deaths occurred among the warm room lot, while 6 were recorded in the cold room; but scarcely any further deaths from natural causes occurred during the next four months, i. e., until the end of the experiment. The cold room individuals. throughout the earlier part of their life, at least, were much less active than those in the warm room. During the first few weeks they kept to their nests almost constantly. Nevertheless, when mature, they were of decidedly better appearance than the warm room lot, and, when paired, they reared a much higher percentage of offspring. It must be added, however, that the reproductive capacity of both lots was found to be distressingly slight-so slight, in fact, as to render futile any attempt to make a satisfactory test of the transmissibility of the modifications which had been produced. Among the 21 females in the cold room lot, $3^{I}$ pregnancies are recorded for the 15 weeks during which they were kept with the males, while in the aggregate only 48 young were reared to the age of six weeks. Indeed, the majority of the litters either consisted entirely of stillborn young, or of ones which died during the first few days after birth. In other cases, the young were apparently born healthy, but the mothers seemed unable to suckle them or perhaps lacked the instinct to do so. With the warm room lot the case was even worse. Of the young resulting from $5^{\circ}$ pregnancies (doubtless over 200 ) only 35 individuals, or about 15 per cent, survived to the age of six weeks, while in the great majority of litters all the individuals died either before or shortly after birth. I am still almost wholly at a loss to account for this failure of the powers of reproduction. The mice were paired rather too young, it is true, being 
$2 \frac{1}{2}$ months old at the time. Many of them did not become pregnant till they were much older than this, however, while it is well known that female mice may bear healthy young at an even earlier age. Again, when judged by most other standards, the animals appeared to be in perfect health. They were active enough, and the fur was commonly in good condition, though the size of the females, at least, even when fully grown, was probably somewhat below normal. Moreover, after the earlier weeks of life, their mortality had been slight. That this damage to the generative powers must be set down as one of the results of the experimental conditions seems, nevertheless, probable.

Measurements at 42 Days. The weight and tail length of these mice was taken at the age of six weeks. ${ }^{21}$ No other measurements were at that time believed to be practicable with the living animals. The following table (no. 3) presents the mean and the index of variability for each of these measurements, the two sexes being treated separately.

TABLE 3

\begin{tabular}{|c|c|c|c|c|c|c|c|c|}
\hline \multicolumn{9}{|c|}{ Series of 1907-1908: Measurements at six weeks of age } \\
\hline & \multicolumn{4}{|c|}{ WIIGHT } & \multicolumn{4}{|c|}{ TAIL LENGTH } \\
\hline & \multicolumn{2}{|c|}{ Males } & \multicolumn{2}{|c|}{ Females } & \multicolumn{2}{|c|}{ Males } & \multicolumn{2}{|c|}{ Females } \\
\hline & $\begin{array}{c}\text { Warm } \\
(29)\end{array}$ & $\begin{array}{l}\text { Cold } \\
\text { (31) }\end{array}$ & $\begin{array}{c}\text { Warm } \\
\text { (33) }\end{array}$ & $\begin{array}{l}\text { Cold } \\
(23)\end{array}$ & $\begin{array}{c}\text { Warm } \\
(29)\end{array}$ & $\begin{array}{l}\text { Cold } \\
\text { (3I) }\end{array}$ & $\begin{array}{c}\text { Warm } \\
\text { (33) }\end{array}$ & $\begin{array}{l}\text { Cold } \\
(23)\end{array}$ \\
\hline \multirow[t]{2}{*}{ Mean. . } & 12.997 & 13.123 & 12.282 & 11.400 & $68.8_{3}$ & $54 \cdot 16$ & 69.06 & $5^{1.91}$ \\
\hline & \pm 0.270 & \pm 0.374 & \pm 0.179 & \pm 0.301 & \pm 0.35 & \pm 0.68 & \pm 0.43 & \pm 0.83 \\
\hline \multirow[t]{2}{*}{ Standard deviation. } & $2.15^{6}$ & 3.088 & 1.517 & $2.13^{8}$ & 2.80 & 5.63 & 3.69 & 5.89 \\
\hline & \pm 0.191 & \pm 0.265 & \pm 0.126 & \pm 0.212 & \pm 0.25 & $\pm 0.4^{8}$ & \pm 0.31 & \pm 0.59 \\
\hline
\end{tabular}

Fig. 2 shows the distribution of weights for the cold and warm room groups (sexes combined); Fig. 3 shows the distribution of tail lengths for the two groups. From the table and polygons collectively the following facts may be gathered:

\footnotetext{
${ }^{21}$ Owing to difference in the date of birth, this age was not attained simultaneously. The great majority, however, were born within the space of a week.
} 
I The tails of the warm room individuals are much longer than those of the cold room individuals. This difference amounts to 27. I per cent for the males, 33.0 per cent for the females, and 29.7 per cent for the sexes combined. Indeed, the two types are so distinct that, but for a single individual, there would be no overlapping of the polygons; i. e. (barring this single exception), the longest tail in the cold room lot was shorter than the shortest in the warm room lot. These differences were so patent to the eye that, had the two lots of mice been mixed together accidentally, I am

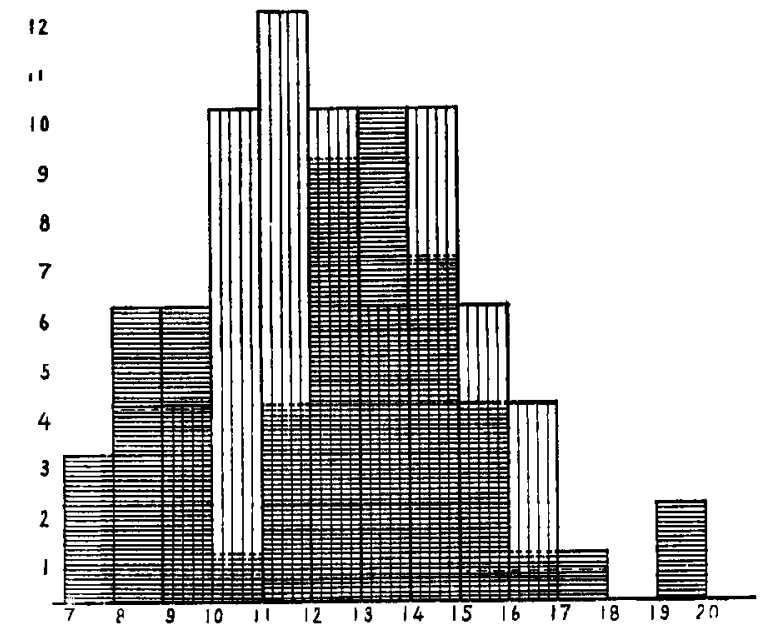

Fig. 2 Series of 1907-1908: weight at six weeks of age (sexes combined). Abscissas denote weight in grams; ordinates denote number of individuals. Vertically shaded areas represent warm-room animals; horizontally shaded areas represent cold-room animals.

sure that I should have been able to separate them again with comparatively few mistakes. Contrary to the condition in the first year's series, a greater difference is here shown by the females.

2 The warm room males were on the average I per cent lighter than the cold room males; the warm room females, on the contrary, were 7.7 per cent heavier. Quite similar relations in respect to weight will be found in the series of the following year. The frequency polygons for weight show that two groups of individuals, having two different "modes," are comprised in the cold room lot - a lighter and a heavier group. An analysis of the individual 


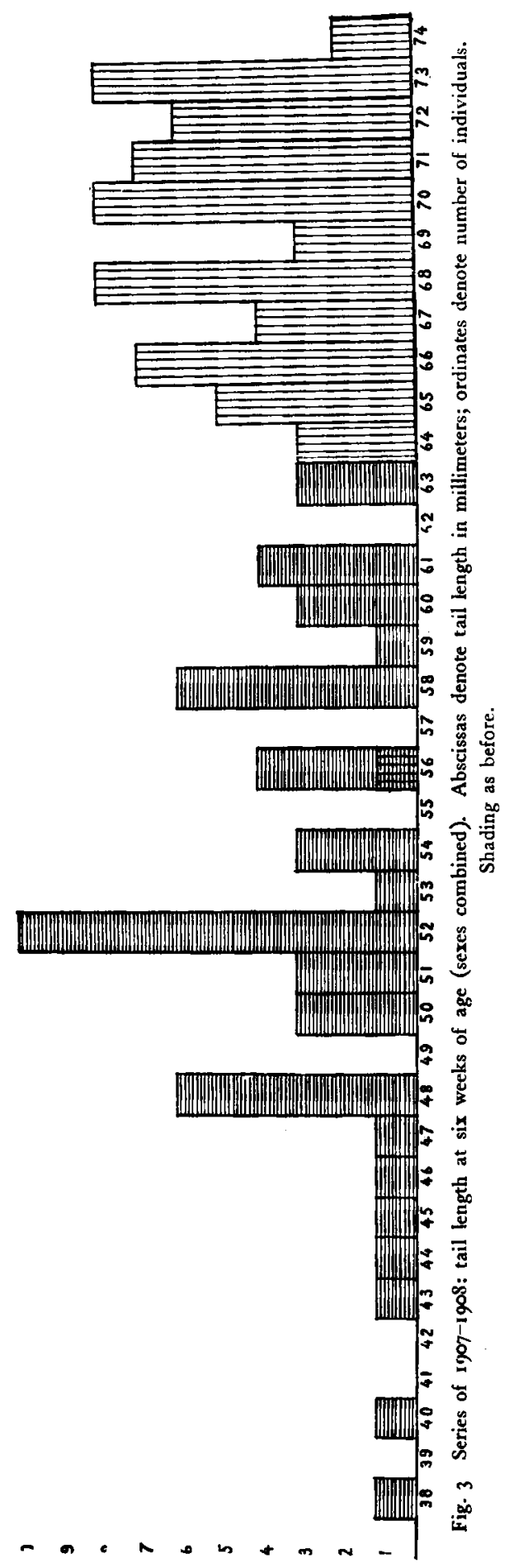


figures shows that both the males and the females are divided quite sharply into these two groups. The number of animals is so small, however, that this phenomenon may be accidental. It will be referred to later.

3 In the case of both sexes, the variability both in weight and in tail length is considerably greater for the cold room lot than for the warm room lot.

4 The mean weight of the males (irrespective of history) is considerably greater ( 9.6 per cent) than that of the females; the tail length seems to bear no constant relation to sex, nor does the variability of either character.

Measurements at $2 \frac{1}{2}$ Months. At the age of $2 \frac{1}{2}$ months the mice were mated. At about the same time (when 75 to 78 days old) the measurements previously made (weight and tail length) were repeated. The number of females surviving to this age was 54 (33 warm + 2 I cold). The number of males reserved for breeding was 13 ( 7 warm +6 cold). There remained 43 males (22 warm +2 I cold) which were not needed for breeding purposes. They were therefore killed at this time, and subjected to a considerably greater number of measurements than had hitherto been employed. At this period, therefore, there are to be considered three groups of individuals (each group consisting, of course, of a warm room and a cold room half) : (I) the females; (2) the mated males; (3) the unmated males.

Referring to Table 4, it will be seen that among the female mice the warm room lot are 4.2 per cent heavier than the cold room lot, while the tail length of the former is 26.6 per cent greater. Comparing the mean figures here given with those of the table for 42 days, it will be found that in the cold room lot the mean weight has undergone an increase of 33.I per cent during the interval between the two measurements, while the mean tail length has undergone an increase of 16 per cent. ${ }^{22}$ In the warm room lot,

\footnotetext{
$n$ Of course this increase in the mean has not exactly the same value as the average individual increase. The latter figure cannot be given for the present series, since the mice had not been marked so as to be individually distinguishable, although the members of each litter were identified by a brood number. Inasmuch as there had been but two deaths in the interval between the measurements, we are dealing with practically the same group in each case.
} 
on the other hand, the increase in weight and in tail length have been 28.8 per cent and 10.3 per cent respectively. There has thus been manifested a tendency toward equalization in respect to both of these characters, but especially in respect to tail length. This appendage has undergone a percentage increase which has been more than half again as rapid in the case of the cold room (i. e., the shorter tailed) as in the warm room (i. e., longer tailed) animals. Further evidence for such a general tendency toward the neutralization of early differences will be offered later. As regards variability, the standard deviation for tail length, both in the warm and cold room lots, has undergone a slight absolute decrease,

TABLE 4

Series of 1907-1908: Females 2 months old

\begin{tabular}{|c|c|c|c|c|}
\hline & \multicolumn{2}{|c|}{ WEICHT } & \multicolumn{2}{|c|}{ LAIL LENGTH } \\
\hline & Warm (33) & Cold (2I) & Warm (33) & Cold (2I) \\
\hline Mean............. & $15.821 \pm 0.261$ & $15 \cdot 176 \pm 0.330$ & $76.18 \pm 0.3^{8}$ & $60.19 \pm 0.7^{6}$ \\
\hline Standard deviation... & $2.221 \pm 0.184$ & $2.226+0.222$ & $3.20 \pm 0.27$ & $5.10 \pm 0.53$ \\
\hline
\end{tabular}

notwithstanding a considerable increase in the average for each lot. The standard deviation for weight, on the contrary, has undergone an increase in each lot. The relative variability (i. e., ratio of standard deviation to mean) has increased in one case (warm room), decreased in the other (cold room).

TABLE 5

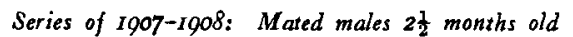

\begin{tabular}{|c|c|c|c|c|}
\hline & \multicolumn{2}{|c|}{ WEIGHT } & \multicolumn{2}{c|}{ TAIL I.ENGTH } \\
\hline & Warm (7) & Cold (6) & Warm (7) & Cold (6) \\
\hline Mean ............. & $17.843 \pm 0.568$ & $20.117 \pm 0.824$ & $78.00 \pm 1.17$ & $66.00 \pm 0.62$ \\
\hline
\end{tabular}

No discussion of the "mated males" (Table 5) ${ }^{23}$ is worth while, owing to the small number of individuals comprised. These

${ }^{23} \mathrm{~A}$ certain degree of selection was exercised in picking out these males, the larger individuals of a brood being chosen for breeding purposes. This is shown by the difference in mean weight between the "mated males" and the "unmated males." 


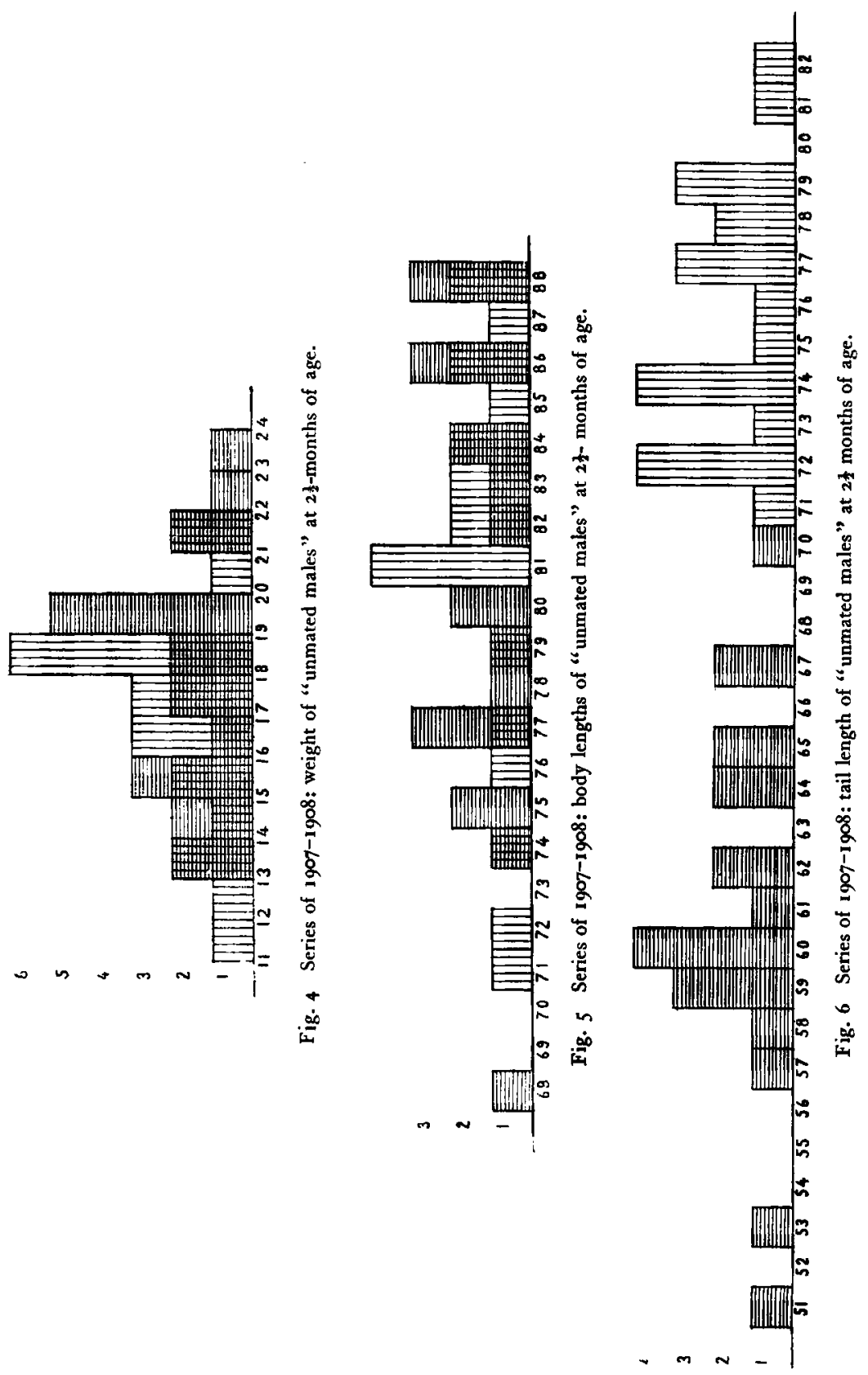


TABLE $6 \mathrm{~A}$

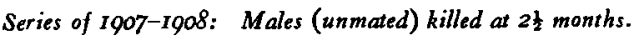

\begin{tabular}{|c|c|c|c|c|c|c|c|}
\hline \multicolumn{8}{|c|}{ WARM ROOM (22) } \\
\hline & Weight & $\begin{array}{l}\text { Body } \\
\text { length }\end{array}$ & Tail & $\begin{array}{c}\text { Caudal } \\
\text { verte- } \\
\text { brae }\end{array}$ & Ear & Foot & $\begin{array}{c}\text { Hair in } \\
\text { 'mg. }\end{array}$ \\
\hline & I 5.5 & 82 & 74 & $3^{2}$ & 13.2 & 16.9 & 328 \\
\hline & $14 \cdot 3$ & 76 & 72 & 33 & 12.6 & 17.1 & 146 \\
\hline & I5.I & 79 & 82 & $3^{2}$ & 13.6 & $17 \cdot 3$ & 350 \\
\hline & 13.8 & 72 & 72 & 33 & 12.7 & 18.2 & 198 \\
\hline & 18.8 & 83 & 74 & $3^{2}$ & I3.0 & 17.0 & 343 \\
\hline & $17 \cdot 7$ & 81 & $7^{8}$ & 33 & 12.4 & 17.2 & 341 \\
\hline & 13.0 & 77 & 73 & 34 & 12.5 & 16.4 & 228 \\
\hline & $18 \cdot 3$ & 86 & 77 & 32 & 13.0 & 17.0 & 271 \\
\hline & 12.3 & 71 & 74 & 31 & 13.0 & $17 \cdot 3$ & 198 \\
\hline & 16.6 & 83 & 77 & $3^{2}$ & $12 \cdot 3$ & $.17 \cdot 5$ & 289 \\
\hline & 21.6 & 88 & 79 & 32 & 13.2 & 17.5 & $37 \mathrm{I}$ \\
\hline & 21.7 & 84 & 79 & $3 \mathbf{I}$ & 13.5 & 16.9 & 318 \\
\hline & $17 \cdot 3$ & 81 & 74 & $3 \mathbf{I}$ & 13.0 & $17 \cdot 9$ & 233 \\
\hline & 16.8 & 81 & 72 & 33 & $12 \cdot 3$ & 17.2 & $25^{8}$ \\
\hline & 18.3 & 87 & 77 & 33 & 13.6 & 17.6 & 279 \\
\hline & 18.7 & 85 & 72 & $3 \mathrm{I}$ & 12.9 & 17.2 & 252 \\
\hline & 16.1 & 81 & 76 & 32 & 13.2 & 17.6 & 229 \\
\hline & I 1.8 & 74 & 71 & 32 & $\mathrm{~J} 3 \cdot 3$ & $17 \cdot 5$ & 130 \\
\hline & 18.8 & 84 & 79 & $3^{2}$ & 13.5 & 18.1 & $26 I$ \\
\hline & 17,2 & 82 & $7^{8}$ & $3^{2}$ & 13.2 & 17.4 & 234 \\
\hline & I8.7 & 86 & $8 I$ & $3^{2}$ & 13.1 & $17 \cdot 5$ & $25^{8}$ \\
\hline & 20.8 & 88 & 75 & $3^{1}$ & 13.0 & 17.6 & $3^{06}$ \\
\hline \multirow[t]{2}{*}{ Mean.. } & 16.964 & $8 I .4 I$ & $75 \cdot 73$ & $3^{2.09}$ & 13.005 & $17 \cdot 359$ & $264 \cdot 59$ \\
\hline & $\pm 0.34^{6}$ & \pm 0.69 & \pm 0.45 & \pm 0. II & $\pm 0.05^{6}$ & \pm 0.055 & $\pm 8.9^{8}$ \\
\hline Standard & 2.724 & 4.78 & 3.11 & 0.74 & $0.3^{89}$ & $0.3^{82}$ & 62.48 \\
\hline Jeviation.. & \pm 0.277 & \pm 0.49 & $\pm 0.3^{2}$ & \pm 0.08 & \pm 0.040 & \pm 0.039 & \pm 6.35 \\
\hline
\end{tabular}


TABLE 6 B

Series of 1907-1908: (Males unmated) killed in $2 \frac{1}{2}$ months.

\begin{tabular}{|c|c|c|c|c|c|c|c|}
\hline & \multirow[b]{2}{*}{ Weight } & \multirow[b]{2}{*}{$\begin{array}{l}\text { Body } \\
\text { length }\end{array}$} & \multicolumn{2}{|c|}{ COLD ROOM (2I) } & \multirow[b]{2}{*}{ Ear } & \multirow[b]{2}{*}{ Foot } & \multirow[b]{2}{*}{$\begin{array}{l}\text { Hair in } \\
\text { mg. }\end{array}$} \\
\hline & & & Tail & $\begin{array}{c}\text { Caudal } \\
\text { vertebra }\end{array}$ & & & \\
\hline & 21.4 & 83 & 59 & $3^{1}$ & 12.6 & 16.4 & 462 \\
\hline & 19.8 & 80 & 60 & 31 & 12.8 & 16.8 & 349 \\
\hline & 14.9 & 74 & 59 & $3^{I}$ & 12.3 & 16.5 & 237 \\
\hline & 18.5 & 77 & 59 & $3 I$ & 12.5 & 16.4 & $3^{28}$ \\
\hline & 17.6 & 79 & 60 & 32 & 12.6 & 17.1 & $33^{\circ}$ \\
\hline & $15 \cdot 7$ & 75 & $6 r$ & 31 & 12.9 & 16.6 & 257 \\
\hline & 15.2 & 80 & 57 & {$[28] *$} & 12.5 & 16.2 & 228 \\
\hline & 13.2 & 75 & 62 & $3^{2}$ & 12.2 & $17 \cdot 4$ & 233 \\
\hline & 16.0 & 78 & $5^{8}$ & {$[29] *$} & 12.0 & 16.0 & 205 \\
\hline & $18 \cdot 3$ & 84 & 64 & 33 & 12.6 & 16.9 & 293 \\
\hline & 15.5 & 77 & 60 & $3^{2}$ & $12 \cdot 3$ & 16.7 & 239 \\
\hline & 13.2 & 68 & 62 & $3^{2}$ & 12.4 & 16.8 & 227 \\
\hline & 23.1 & 88 & 64 & 33 & 13.5 & 17.5 & 364 \\
\hline & 22.7 & 88 & 65 & 32 & 13.3 & $17 \cdot 5$ & 502 \\
\hline & 14.7 & 77 & $5^{1}$ & 30 & 12.2 & 16.3 & $21 I$ \\
\hline & 17.2 & 82 & 53 & $3^{2}$ & 12.2 & 16.3 & 225 \\
\hline & 21.8 & 86 & 60 & $3 I$ & 13.0 & 16.9 & 284 \\
\hline & 19.5 & 86 & 70 & 33 & 14.0 & 17.2 & 255 \\
\hline & I9.3 & 88 & 67 & $3^{\circ}$ & 13.4 & $17 \cdot 3$ & 284 \\
\hline & 19.0 & 84 & 65 & $3^{2}$ & $13 \cdot 5$ & 16.7 & $3^{8} 3$ \\
\hline & 19.4 & 86 & 67 & $3^{I}$ & 13.7 & $17 \cdot 3$ & 294 \\
\hline Mean. . & 17.905 & 80.71 & 61.10 & $3^{1} \cdot 5^{8}$ & $12.7^{86}$ & 16.800 & 294.76 \\
\hline & \pm 0.425 & \pm 0.78 & \pm 0.65 & \pm 0.14 & \pm 0.082 & \pm 0.065 & \pm 11.66 \\
\hline Standard & 2.888 & $5 \cdot 33$ & $4 \cdot 4 I$ & 0.88 & $0.55^{8}$ & 0.441 & $79 \cdot 17$ \\
\hline deviation.. & $\pm 0.3^{01}$ & \pm 0.55 & $\pm 0.4^{6}$ & \pm 0.09 & $\pm 0.05^{8}$ & \pm 0.046 & \pm 8.24 \\
\hline
\end{tabular}




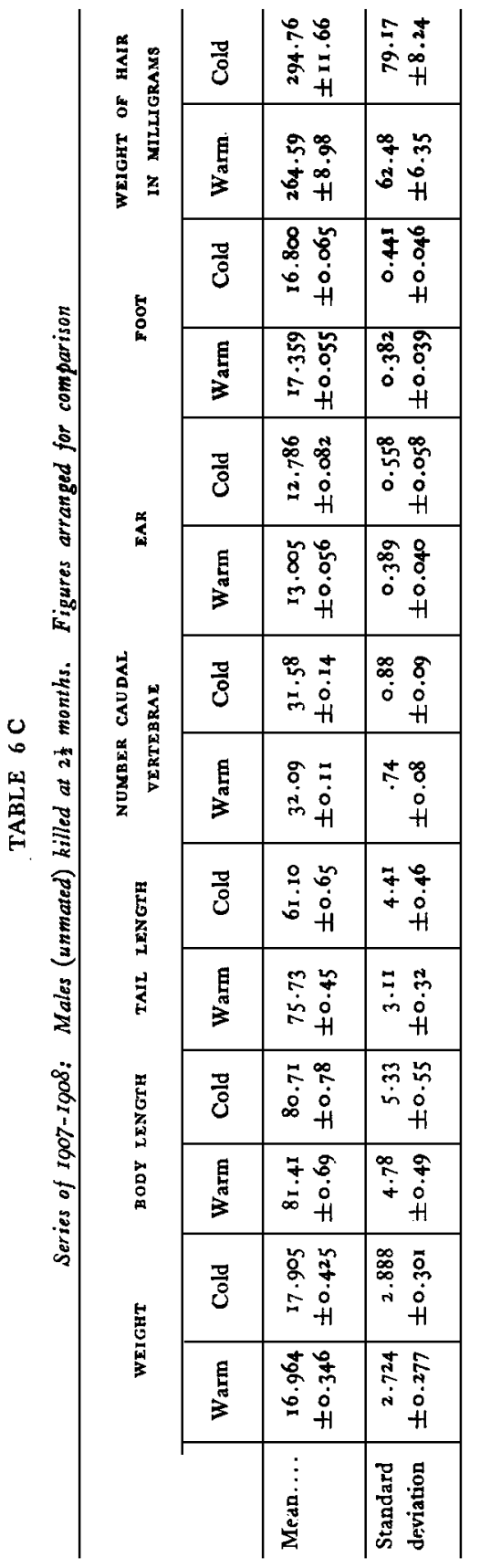


figures will be later combined, however, with certain of those given for the next group.

The unmated males, measured at the age of $2 \frac{1}{2}$ months, constitute the most important group in the second year's series. Table 6 $(A, B$, and $C$ ) presents the measurements for these 43 mice. These measurements were all made after killing.

Comparison of these figures with those given for the males at 42 days is of course only possible in respect to two charactersweight and tail length. In order to determine accurately what changes have occurred in these, however, we must first combine the figures for the present group with the preceding group of "mated males," since the two together comprise the entire collection of males which had been measured earlier in life. ${ }^{24}$ Table 7 accordingly represents the mean weight and tail length for all males at the age of $2 \frac{1}{2}$ months.

TABLE 7

Series of 1907-1908: All males at $2 \frac{1}{2}$ months of age

\begin{tabular}{c|c|c|c|c|}
\hline \multirow{2}{*}{} & \multicolumn{2}{|c}{ WEIGHT } & \multicolumn{2}{c|}{ TAIL LENGTH } \\
\cline { 2 - 5 } & Warm (29) & Cold (27) & Warm (29) & Cold (27) \\
\hline Mean............. & $\mathbf{1 7 . 1 7 6}$ & $\mathbf{1 8 . 3 9 6}$ & 77.41 & 63.33 \\
& $\pm 0.33 \mathrm{I}$ & \pm 0.396 & \pm 0.44 & \pm 0.56 \\
Standard deviation... & 2.646. & 3.053 & \multicolumn{3}{c}{3.54} & 4.28 \\
& \pm 0.234 & $\pm 0.28 \mathrm{I}$ & $\pm 0.3 \mathrm{I}$ & \pm 0.39 \\
\hline
\end{tabular}

Comparing these figures with those of the males at six weeks of age, we note that whereas the tails of the cold room lot have increased 16.9 per cent in the interval between the measurements, those of the warm room lot have increased only 12.5 per cent. There is thus seen to be a tendency to "catch up" on the part of the less developed organs, which has already been pointed out for

\footnotetext{
${ }^{24}$ In combining these figures an allowance is first necessary. The tail length of the dead mice was, as stated above (p. I03), obtained by a different method from that practised upon the living ones. I have found that in living mice of this size the tail is stretched on the average about $1.5 \mathrm{~mm}$. during the suspension. This amount has accordingly been added to the mean tail length of the unmated males before combining with that of the mated males. The resulting figure represents approximately the tail length which would have been obtained had all been measured alive.
} 
the females and will be discussed later. It must be added, however, that in the present case the difference in weight between the two groups has increased rather than diminished. In respect to variability, two of the four standard deviations comprised in the table show an absolute decrease, one of the others indicates a slightly lessened variability, while in the fourth case there is an increase, both absolute and relative. Not much importance is to be attached to these latter comparisons, however.

Returning to a consideration of the figures presented in Table 6 it is seen that the weight is 5.3 per cent less in the warm room lot than in the cold room lot; while the body is seven-tenths of one per cent longer and the tail 23.9 per cent longer. Passing to the new measurements (not applicable to living animals), the average length of the (left) ear is $I .7$ per cent greater in the warm room lot; that of the foot 3.3 per cent greater. The average weight of hair (see p. IO2) for the cold room mice is II.4 per cent greater than that of the warm room individuals. It has seemed worth while to represent graphically the frequency distributions of these characters (Figs. 4 to 9). The difference in weight between the two sets of mice (Fig. 4) cannot with any certainty be regarded as a significant one. The difference in body length (Fig. 5) is too trivial to be taken into consideration.

In striking contrast, however, is the case for tail length (Fig. 6). Here there is no overlapping whatever of the polygons, while the modes are removed by a distance of $13 \mathrm{~mm}$. Two questions present themselves respecting this difference of tail length: (I) Does it involve an actual difference in the volume of the organ? And (2) does it involve a difference in the number of vertebra? In order to test the first question the diameter of the tail at its widest point was obtained by means of calipers for all the mice of this group. While this is a difficult measurement to make with any great accuracy, the figures are probably exact enough for present purposes. The averages for warm room and cold room animais are $2.94 \mathrm{~mm}$. and $3.02 \mathrm{~mm}$., respectively. There is thus the possibility of a slightly greater attenuation of the tail, accompanying its more rapid increase in length, but the former is certainly nothing like proportionate to the latter. There is 
therefore an actual difference in the volume of the tail. The number of caudal vertebra was likewise counted for all of this

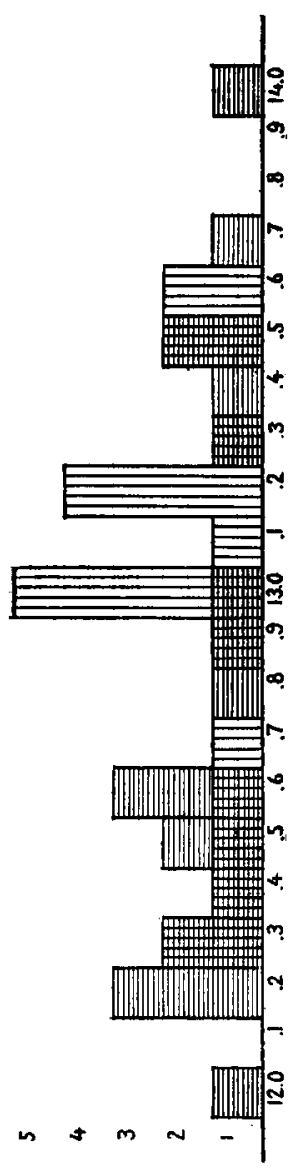

Fig. 7 Series of 1907-1908: ear length of "unmated males" at $2 \frac{1}{2}$ months of age.

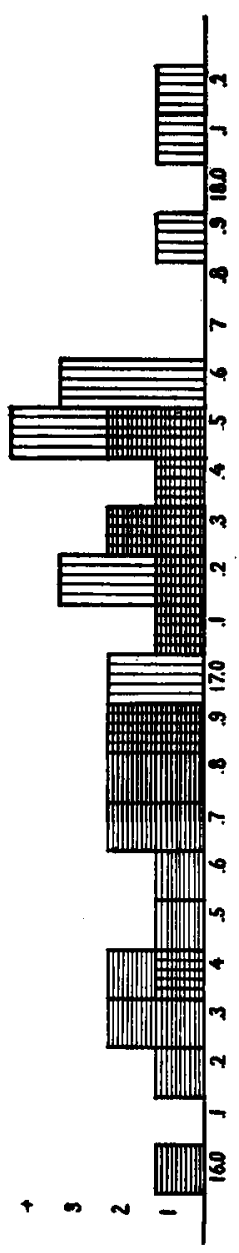

Fig. 8 Series of 1907-1908: foot length of "unmated males" at $2 \frac{1}{2}$ months of age.

group. The mean figures are given in the table ${ }^{25}(6)$, where it is seen that the difference between the two groups (if significant

${ }^{25}$ The number of vertebræ was counted, from the sacrum to the last nodule of bone distinguishable under a low power objective. The task was comparatively simple and admitted of tolerable accuracy. The average error of observation was probably less than one vertebra per mouse. Since the skele- 
at all) amounts to only about half a vertebra, i. e., it is not sufficient to make any appreciable difference in the tail length. In fact there is very little deviation from the mean throughout the entire series. It would be surprising indeed if the number of vertebræ had been found to be altered by temperature conditions, first because this number does not in all probability vary very widely in most species of mammals, and, secondly, because the definitive division of the embryonic tissues into vertebræ is probably complete long before birth.

The present difference in ear length is not convincing, but foot length, has, with practical certainty, been affected by the tempeature conditions.

It must be remembered that we are here dealing with mice which differ among themselves widely in size, and that neither the mean weight nor the mean body length is quite the same for the two groups. In Table 8 are presented the relative magnitudes of certain characters. Here we have the mean ratios between the length of tail, ear and foot in each individual and the length of the body; likewise the ratios between the weight of the hair and the square of the body length. In the case of the ear and the foot, the variability of the ratios is found to be much greater than that of the absolute measurements. This is due to the fact that these parts vary but slightly as compared with the size of the animals. Indeed their length is remarkably constant throughout each series, irrespective of the body length of the individual.

The case of the hair deserves a rather full discussion, since this is the character, in particular, whose modification may be supposed to be of an adaptive nature. It is seen from Table 6 that the mean weight of the pelage for the cold room individuals is 11.4 percent greater than that of the warm room individuals. The variability is very high, to be sure, partly because the animals vary much in size, partly because they actually vary in the density of their hair

ton was not thoroughly denuded of muscles, etc., (alcoholic specimens were used) it was not always easy to distinguish the termination of the sacrum and the commencement of the caudal series, and an error of one or two vertebra perhaps resulted occasionally from this cause. In a few instances, some of the minute terminal vertebræ were lacking, owing to obvious injury to the tail. In such cases, the figures have been enclosed in brackets and have not been included in making up the averages. 


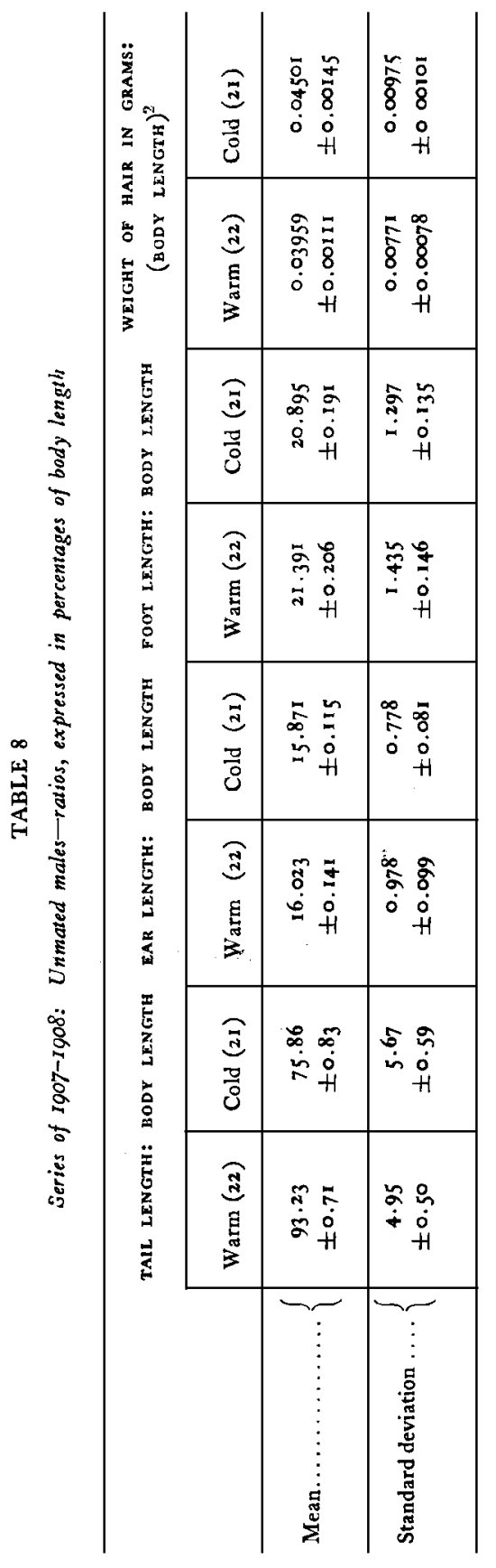


coat. I have therefore made an endeavor to compute the relative amount of hair, making allowance for the area of the skin - that is, I have obtained the ratio between the hair weight of each mouse and the square of its body length. The mean of these figures is $0.045^{\circ} \mathrm{I} \mathrm{mg}$. per sq. $\mathrm{mm}$. for the cold room lot, 0.03959 for the warm room lot. According to this computation, the cold room mice have a relative amount of hair 13.6 per cent greater (heavier) than the warm room ones. It must be admitted, however, that such a method of computation is open to criticism. To estimate the relative skin areas of these mice by comparing the squares of their body lengths presupposes that they are, in the language of geom-

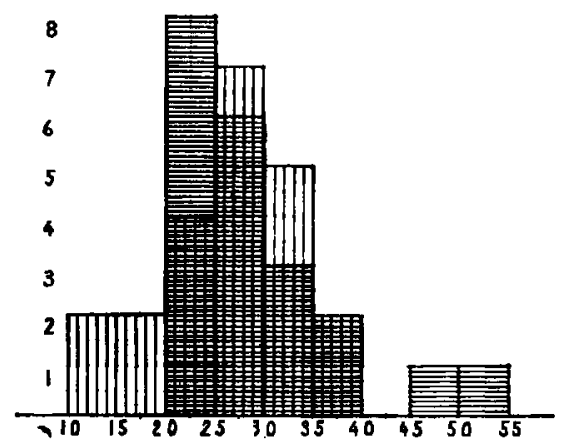

Fig. 9 Series of 1907-1908: weight of hair (absolute) of "unmated males" at $2 \frac{1}{2}$ months (expressed in hundredths of a gram).

etry, "similar solids," which they are not. As a matter of fact, while the warm room mice have a slightly greater bodylength than the contrasted group, they are lighter, on the average, by nearly one gram, i. e., a difference of over 5 per cent. They are probably somewhat less plump, therefore. I must add, however, that I do not believe any such slight difference of shape to be accountable for the difference in the amount of hair which is shown by the two groups of mice. The most serious criticism of these figures relates to the number of individuals, which is confessedly too small to permit of our drawing any final conclusions in the presence of such high variability. 
Until further data are available, however, it seems worth while to offer them for what they are worth.

Fig. 9 shows the distribution of hair weight for the entire lot, both the hot room and the cold room individuals. No fair comparison can be drawn from these polygons, as has already been stated, since mice of very different sizes are represented. In Fig. Io I have substituted in each case for the absolute weight the ratio of the hair weight to the square of the body length. While the modes lie at the same point, the centers of gravity are considerably separated.

In view of statements cited by Lydekker ${ }^{28}$ regarding certain modifications which are alleged to have been produced in cats by

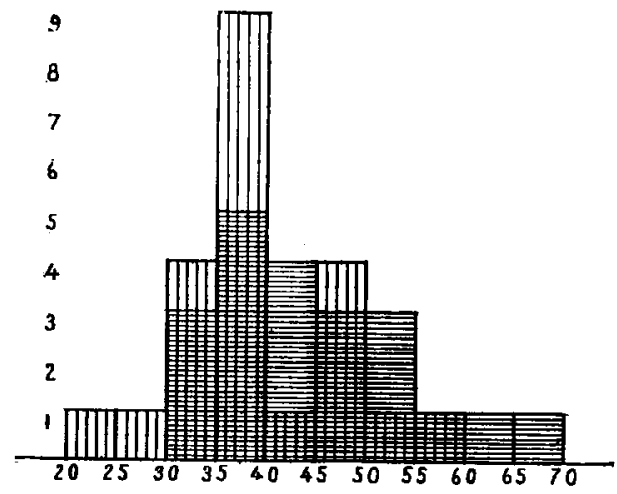

Fig. 10 Series of 1907-1908: weight of hair (relative) of "unmated males" at $2 \frac{1}{2}$ moaths (= ratio of hair-weight to square of body length).

life in a cold-storage warehouse, I endeavored to determine for the present group of mice whether there was any appreciable difference in the length of the vibrissæ between cold room and warm room individuals. The measurements have necessarily been rough in the extreme. The longest hair among the "whiskers" of one side was measured by calipers, without straightening or removing it. The mean figures obtained were $26.8 \mathrm{~mm}$. for the warm room lot; 25.4 for the cold room lot. Considering the crudity of the method, the individual measurements vary compara-

20 A Handbook to the Carnivora. Part I: Cats, etc.; Pp. 158-163. 
tively little, though enough, probably, to deprive this difference of any significance. No such obvious modifications as has been alleged for cats ${ }^{27}$ is here evident.

Measurements at 7 Months. The subsequent history of the female mice varied considerably with different individuals, according to the exigencies of the breeding experiments. Each female from either lot, as she became pregnant, was transferred to a room kept at a temperature somewhat intermediate between the hot and cold rooms. If, as was commonly the case (see p. II6), her brood did not survive, she was taken back to the room from which she came. Thus, in the interval between February 6 and April I, a considerable proportion of the females were transferred back and forth between the warm or cold room and the "intermediate" room, in some cases more than once. I have not thought it worth while to compute the average duration of each set of conditions for the lot. On April I, all the mice were moved to the "intermediate" room and the sexes separated. On May I, they were paired again, but with the same unfortunate results. The entire lot of females was killed and measured between June 4 and July 6 . All were about 7 months of age at the time of killing, save for a few mothers of broods, which were allowed to remain with the latter till they were old enough to take care of themselves. These somewhat older individuals ( $7 \frac{1}{2}$ to 8 months) have, however, been included in the table herewith given. As they were, with little doubt, all fully grown, this proceedure seems fair.

The mean figures obtained for each lot of females is given in Table 9. It herewith appears that the weight in the warm room lot is 2.4 per cent greater than in the cold room lot, the body twotenths per cent longer, the tail 14.9 per cent longer ${ }^{28}$ the foot 4.1 per cent longer, while the average ear length is practically equal in the

\footnotetext{
${ }^{27}$ It is true that in the case cited by Lydekker the elongation of the vibrissa was attributed to the darkness, rather than to the cold.

${ }^{28}$ It seems probable that, so far as the tail at least is concerned, the cold-room mice have departed from the more usual or normal condition, while the warm-room individuals bave been little if any modified. Fifty-nine adult female mice, of unknown history, which were received by me during the present winter, had a mean tail length of $92.8 \mathrm{~mm}$.; i. e., their tails were considerably longer than even the warm-room females of Table 7. It must be noted, however, that they were larger mice, having a mean weight of $26.6 \mathrm{gms}$.
} 


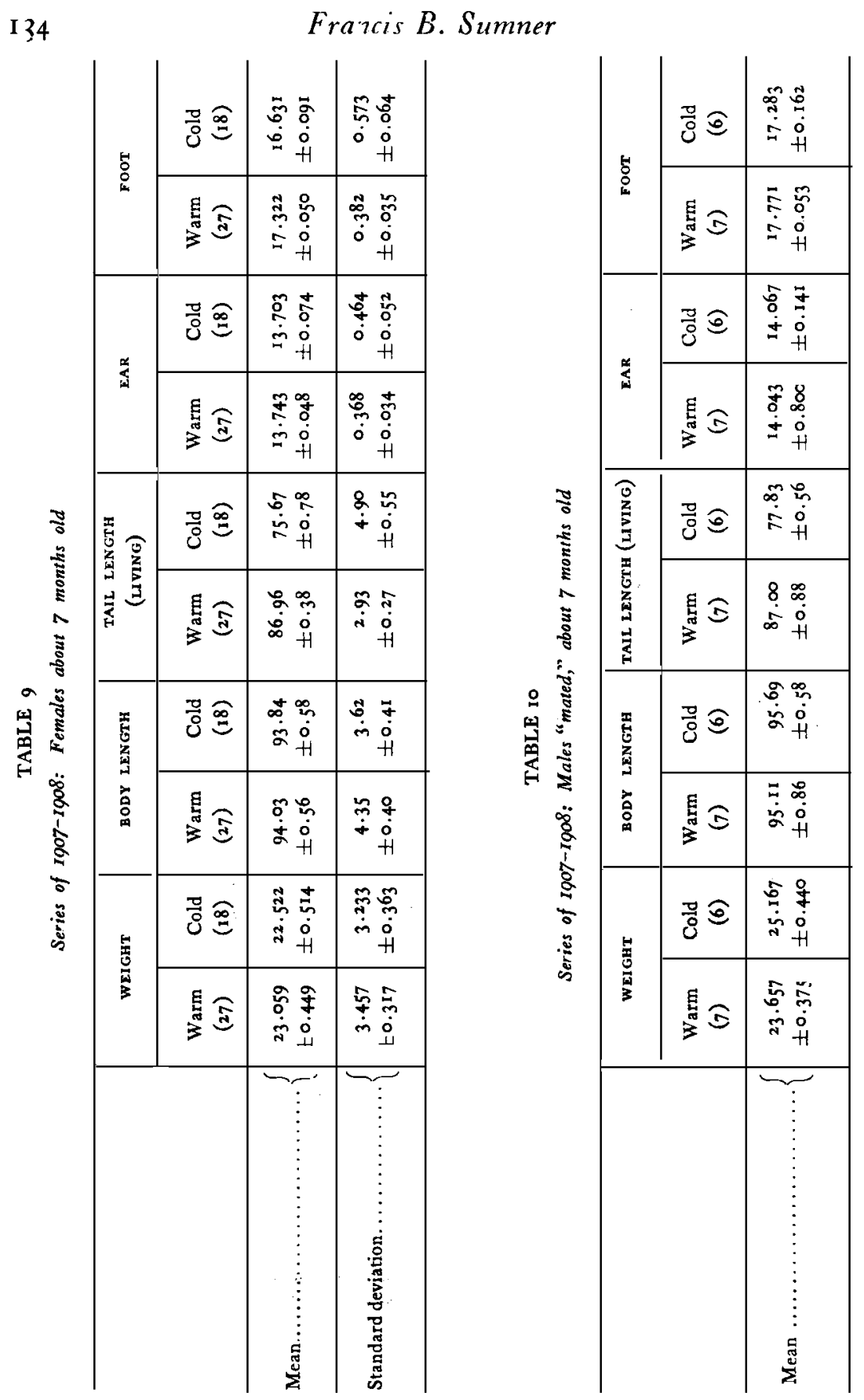


two lots. None of these differences except those in the length of the tail and foot are to be regarded as having any significance.

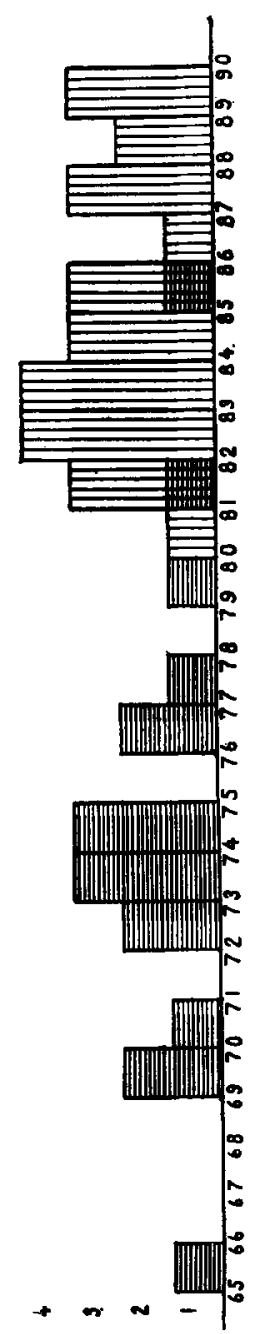

Fig. I1. Series of 1907-1908: tail length of females at 7 months of age (based upon measurements after death-see text.)

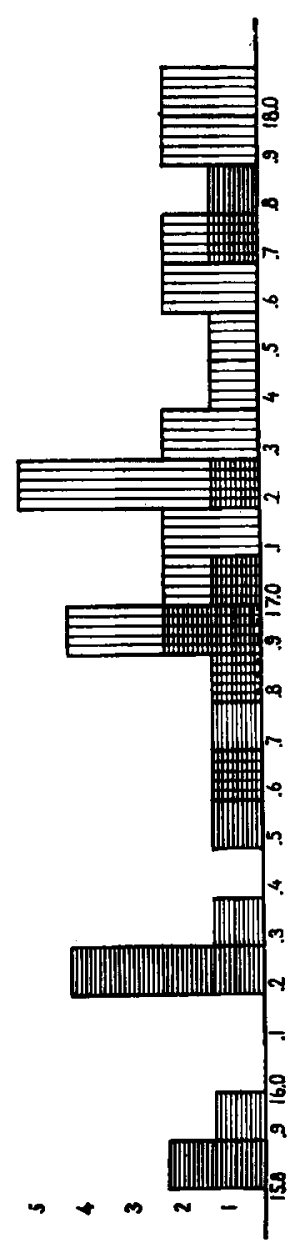

Fig. I2 Series of 1907-1908: foot length of females at 7 months of age.

Comparing the measurements for this age with those (weight and tail) made upon these same mice ${ }^{2 \theta}$ when $2 \frac{1}{2}$ months old, we find

${ }^{29} \mathrm{Six}$ of the warm-room lot and three of the cold-room lot had died in the meantime. 
that the weight has increased during this interval 48.4 per cent in the cold room (i. e., lighter) lot; 45.8 per cent in the warm room (heavier) lot. The gain in tail length for the cold room lot has been 25.7 per cent, as compared with an increase of only $\mathbf{I} 4.2$ per cent on the part of the warm room individuals. In respect to each character, therefore, but more especially in respect to the tail, there has been a very obvious tendency toward a diminution of the differences between the two contrasted sets.

Referring to variability, a comparison of the standard deviations for tail length shows that there has been a slight reduction in the absolute and a considerable reduction in the relative variability in both the warm room and cold room lots. The standard deviations for weight have undergone an increase in each lot, though the relative variability has remained practically unchanged.

Frequency polygons (Figs. II and I2) have been plotted for tail length and foot length in this group of females. The polygons for the former overlap to a very slight extent; those for the latter are sufficiently distinct to admit of no doubt as to their significance.

The males used for breeding were kept under the extreme temperature conditions until April I, at which time they were 4 to 5 months old. They were then transferred to the "intermediate room" along with the females, and were killed upon reaching the age of 7 months.

Thel measurements for this group are given in Table ro.

Comparing the present figures with those for the same mice at the age of $2 \frac{1}{2}$ months, we find that the lighter warm room lot has gained to the extent of 32.7 per cent of its former weight, while the heavier cold room lot has gained only 25.1 per cent, again showing a tendency toward equalization. The same fact is evident in the growth of the tail. This has amounted to 17.9 per cent in the case of the cold room lot; I r.5 per cent in the case of the warm room lot.

\section{Levelling Down of Early Differences.}

Reference has more than once been made, in discussing particular sets of measurements, to a tendency for these experimentally produced differences to diminish with growth. A table has been 
prepared (Table II) which includes all the cases in which this point can be tested.

TABLE $1 \mathrm{I}$

Series of 1907-1908: percentages of increase* in the intervals between successive measurements

\begin{tabular}{|c|c|c|c|c|c|c|c|}
\hline & & \multicolumn{2}{|c|}{$\begin{array}{c}6 \text { wEEKS } \\
\text { ABSOLUTE MEASURE- } \\
\text { MENTS }\end{array}$} & \multicolumn{2}{|c|}{$\begin{array}{l}2 \frac{1}{2} \text { MONTHS } \\
\text { PERCENTAGES OF } \\
\text { INCREASE }\end{array}$} & \multicolumn{2}{|c|}{$\begin{array}{c}7 \text { MONTHS } \dagger \\
\text { PERCENTAGES OF } \\
\text { INCREASE }\end{array}$} \\
\hline & & Weight & $\begin{array}{l}\text { Tail } \\
\text { length }\end{array}$ & Weight & $\begin{array}{c}\text { Tail } \\
\text { length }\end{array}$ & Weight & $\begin{array}{c}\text { Tail } \\
\text { length }\end{array}$ \\
\hline Males . & 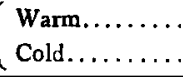 & $\begin{array}{l}12.997 \\
13.123\end{array}$ & $\begin{array}{l}68.83 \\
54.16\end{array}$ & $\begin{array}{l}32.1 \% \\
40.2 \%\end{array}$ & $\begin{array}{l}12.5 \% \\
16.9 \%\end{array}$ & $\begin{array}{l}32.7 \% \\
25.1 \%\end{array}$ & $\begin{array}{l}11.5 \% \\
17.9 \%\end{array}$ \\
\hline Females & $\left\{\begin{array}{l}\text { Warm.......... } \\
\text { Cold.......... }\end{array}\right.$ & $\begin{array}{l}12.282 \\
11.400\end{array}$ & $\begin{array}{l}69.06 \\
51.91\end{array}$ & $\begin{array}{l}28.8 \% \\
33.1 \%\end{array}$ & $\begin{array}{l}10.3 \% \\
16.0 \%\end{array}$ & $\begin{array}{l}45.8 \% \\
48.4 \%\end{array}$ & $\begin{array}{l}14.2 \% \\
25.7 \%\end{array}$ \\
\hline
\end{tabular}

*See foot note on p. 120 above.

tIn considering the figures for 7 months, it must be recalled that only 13 males 6 warm +6 cold) have been kept till this time. In figuring percentages of increase for these males, therefore, the later figures have. been compared with those for this same group of "mated males," and not with those for the males in general. In the column for $2 \frac{1}{2}$ months, on the contrary, the figures for "all males" are given.

Under the "6 weeks" column, we have the absolute measurements of weight and tail length for males and females belonging to the warm room and cold room lots. In the column for $2 \frac{1}{2}$ months is given for each group the percentage of increase of each of these characters, during the interval between the two measurements. In the " 7 months" column are given the percentages of increase over the measurements for $2 \frac{1}{2}$ months. For each sex are presented two horizontal rows of figures: those for the "warm" and the "cold" lots respectively. It is thus easy to compare the contrasted figures for any one character. In each pair of these contrasted figures, that one has been printed in heavy type which represents the rate of increase for the group which had previously shown a lower mean value for the character in question. This group should, according to the hypothesis, be expected to have undergone a more rapid rate of increase. As a matter of fact, it will be noted that in 7 out of the 8 pairs of contrasted figures, the 
number in heavy type is the larger number. ${ }^{30}$ This decrease in bodily differences originally brought about by differences of temperature has not been due to a withdrawal of the latter. Indeed, during the interval between the " 6 weeks" measurements and the " $2 \frac{1}{2}$ months" measurements the temperature differences in the two rooms have increased rather than diminished. (See Fig. I.) Later, it is true, the temperature differences gradually diminished, and commencing with April 2 they were abolished altogether. At the latter date, however, the mice averaged nearly five months old, and their growth was probably not far from complete.

While the tendency toward a reduction of the original differences between the warm and the cold room groups is thus pretty clear, the evidence for a reduction of variability within each group is not so certain. An inspection of the tables shows us twelve cases in which we can compare a later standard deviation with an earlier one for the same character. In six of these cases the later standard deviation is smaller, $i$. e., the decrease in variability has been absolute as well as relative. In two cases there has been a relative decrease, though not an absolute one; while in two others, the relative variability has remained practically unchanged. In only two of the twelve cases has there been any appreciable increase in the relative variability. In view of the lack of uniformity in these results, however, and the commonly high probable errors, too much significance must not be attached to them. It is worth pointing out, however, that the variability for tail length has decreased absolutely as well as relatively in five out of six cases.

$$
\text { Series of } 1908-1909
$$

At the date of writing, the experiments of the third winter have not been carried very far. A first and second series of measurements upon the living mice have, however, been made, and the results seem well worth comparing with those of the preceding

\footnotetext{
${ }^{30}$ It is likewise true that in all of these seven cases there has been a greater absolute gain as well as a greater percentage increase. Rate of growth seems more fairly expressed, however, in terms of proportionate increase.
} 
year. ${ }^{31}$ The temperature conditions during the first four months are indicated in Fig. $I$, in which a certain degree of comparison with those of the previous winter is made possible. The mean temperature of the warm room during the first three months of

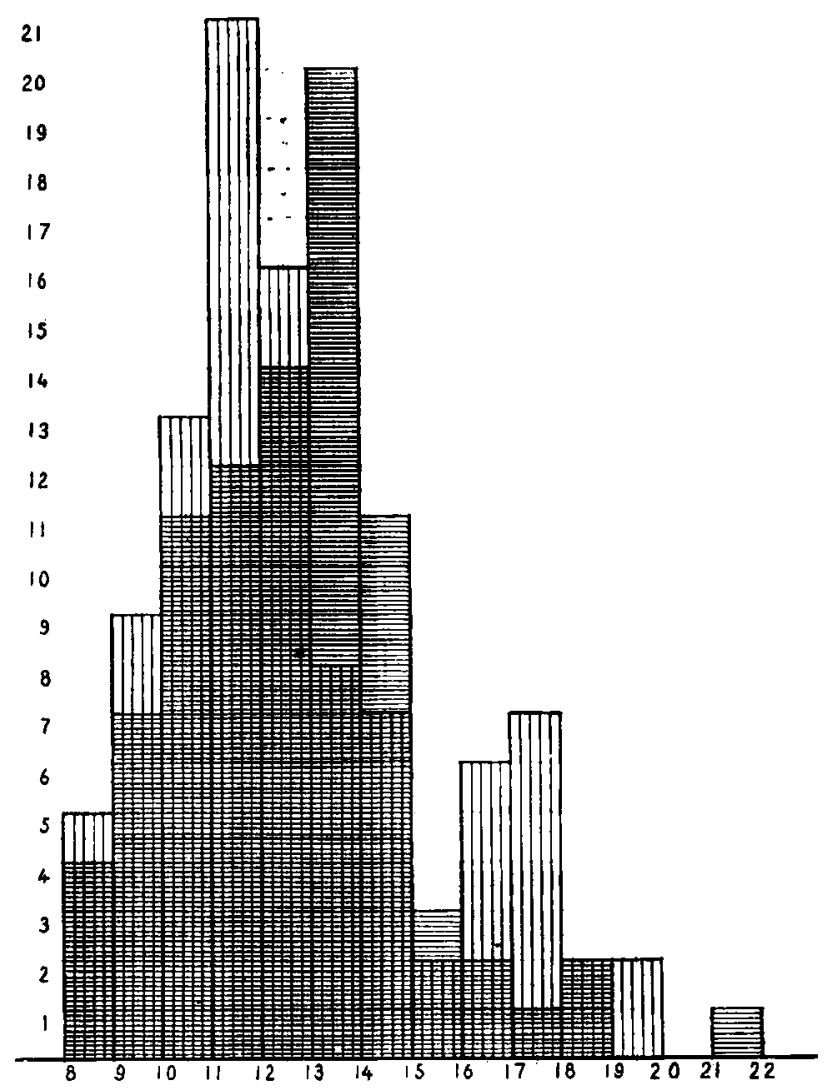

Fig. I3 Series of 1908-rgog: weight at six weeks (sexes combined).

the animals' lives was $21.3^{\circ} \mathrm{C}$, with a mean daily range of $12^{\circ}, \mathrm{C}$. In the cold room the mean temperature during this same period was $3.6^{\circ} \mathrm{C}$., the range of daily fluctuation being $6^{\circ}$. The temper-

\footnotetext{
${ }^{31}$ The mice here used are from an entirely new stock, none of them being descendants of those raised during the preceding year. Animals from several different localities, having independent pedigree, are comprised in the lot. In the present series individual litters were not divided into a "warm room" and "cold room" half, as had been done with those of the preceding year.
} 
ature conditions will be further discussed after the first table of measurements has been presented. The mean relative humidity in the warm room ( 12 determinations) was 38.5 per cent, a figure very close to that of the preceding year. The humidity of the cold room (I 4 determinations) was 76.5 per cent, being thus considerably greater than that of the preceding year. This is accounted for by the fact that the cold room used during the present year has been situated in a building which is entirely unheated.

With respect to weight there is a remarkably close agreement between each of the four averages here presented and the corresponding one of the preceding year. In each year's series, the males are larger in the cold room lot, while the females are larger in the warm room lot. From the magnitude of the probable errors, however, we cannot feel sure of the validity of these differences. ${ }^{32}$

Regarding tail length, it will be noted that the differences, while considerable, are very much smaller than those to be found in Table 3. The warm room males have tails which are Ir.8 per cent longer than those of the cold room lot. This difference, in the case of the 1907-1908 lot, was 27.1. The warm room females show a mean tail length which is 15.9 per cent greater than that of the cold room individuals, as compared with a difference of 33 per cent in the earlier lot. Thus, as in the preceding year's measurements, we find that it is the females which have been modified most in this respect. But the amount of modification for each sex has been less than half that which was earlier observed. Regarding variability no deductions of interest are to be drawn. No such evidence of a higher variability in the cold room lot as was previously noted is here to be found. In fact, the reverse is possibly true.

The salient fact brought out by this comparison is the relatively small degree of modification in the tail length of the present lot of animals. This fact is not satisfactorily explained by a comparison of the temperature conditions for the two years. We find, it is true, in the later series a somewhat smaller difference in temperature between the two rooms during the first six weeks of the

\footnotetext{
${ }^{32}$ See supplementary note below.
} 


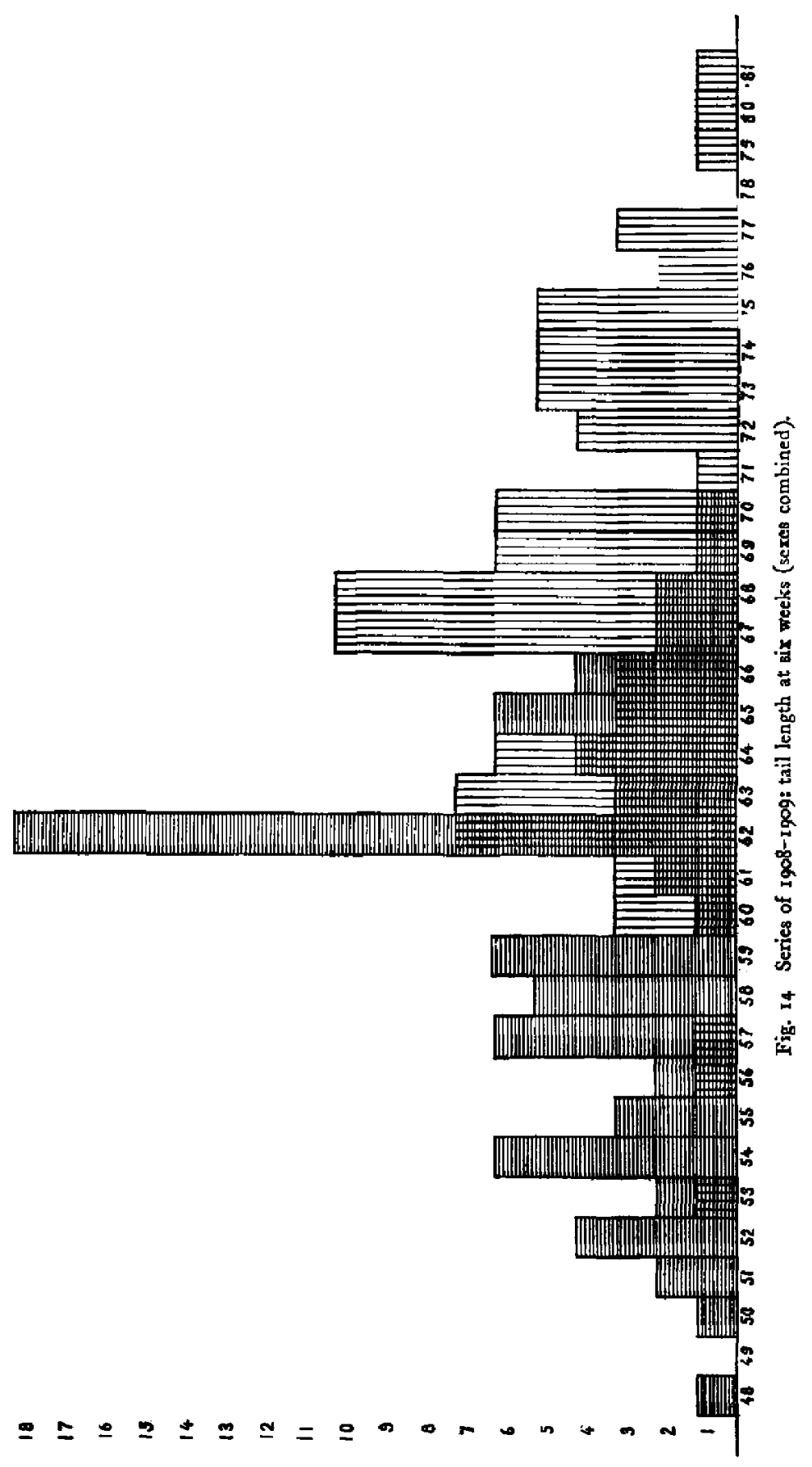


animals' lives. This difference here amounts to $14.5^{\circ} \mathrm{C}$, as compared with $16.6^{\circ}$ during the winter of $1907-1908$; and it might be at once inferred that in this fact we had a key to the difference of results. It must be noted, however, that, while the warm room temperature has been considerably lower for this period, during the later year ( $19.8^{\circ}$ as compared with $23.7^{\circ}$ ), the cold room temperature has likewise been somewhat lower $\left(5.3^{\text {oss }}\right.$ as compared with $\left.7 \cdot 2^{\circ}\right)$. Now a comparison of Tables 3 and 12 shows us that while the warm room tails agree pretty closely in length in the two series, the cold room tails are much shorter in the earlier one

TABLE 13

Series of 1908-1909: percentages of increase in the interval between successive measurements

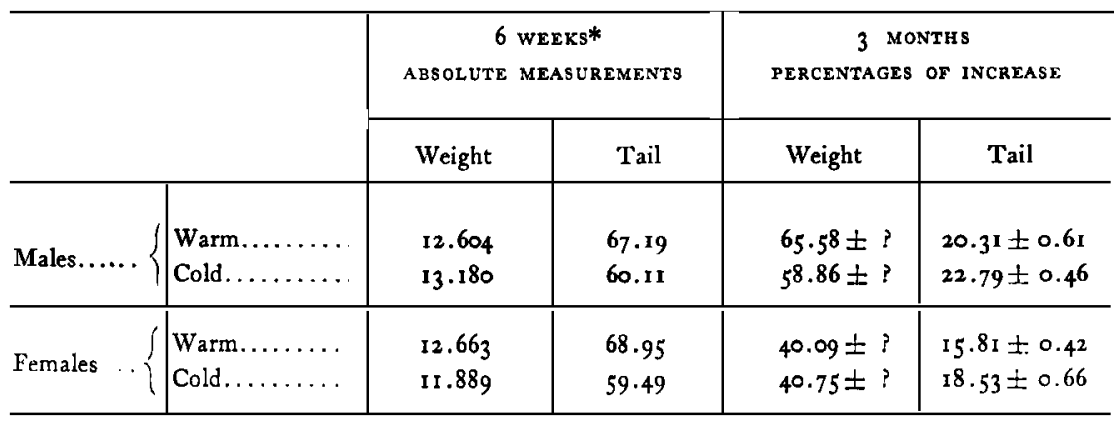

* See Table I 2 .

Were these modifications simple functions of the temperature differences, we should not have expected such a state of things. Indeed the author has no explanation to offer for the striking difference between the two years' results.

A second set of measurements was made upon the same mice at the age of three months. The statistical treatment of these later figures is not yet quite complete. I have determined, however, the mean percentage increase in weight and tail length for each sex, both in the warm room and the cold room lots. Since every

\footnotetext{
${ }^{33}$ This is the figure for the room in which the thermograph was kept, and in which most of the mice lived during the greater part of this period. For certain reasons, however, all of the animals were kept for a period of varying length ( 8 to 42 days - the last in the case of only one brood) in another room, having a mean temperature about $4^{\circ}$ higher than that of the room first referred to. This fact of course complicates the situation somewhat.
} 
mouse in the present year's experiments is identified by a mark of its own, it has been possible to compute the rate of increase for each animal individually. In Table $I_{3}$ are presented the mean percentages of increase for each character during the period in question.

It will be seen from this table that in all four cases the figure expressing the increase in a character is larger in that group in which the previous absolute measurement had been smaller. It must be added, however, that in neither case is the figure for weight of any significance in this connection, despite the differences between the averages. The variability in the weight-increase has been enormous (ranging from 9 per cent to 143 per cent), so that the probable errors (not yet computed) are undoubtedly very large. For the growth of the tail, however, the case seems fairly certain. It will be recalled that in the preceding series it was the figures for tail length which bore the strongest testimony to the principle of the leveling down of original differences. Reference to the temperature curves shows that here, as previously, the differences in the conditions have increased rather than diminished during this period. As regards the increase or decrease in variability within each lot, nothing can be said here, since the standard deviations have not been computed for the 3-months measurements.

Supplementary. A yet later series of animals (born March I909), consisting of a larger number of individuals than any of the preceding lots, kas yielded, after similiar teatment, the following results: (I) a difference in tail length somewhat greater than that shown in the preceding series ( 16.7 per cent in the present case); (2) an indubitable difference (both absolute and relative) in foot length, which applies equally to both sexes and fully confirms the earlier conclusions on this point; (3) a similar difference in ear length, which, however, is of far less certain significance; (4) a difference in weight, both sexes being heavier in the warm room lots (cf. pp. I 8 , I 38 above),'although this difference was greater for the females (Ir.3 per cent) than for the males (9.I per cent). The temperature differences to which the animals were subjected had already begun to diminish at the time of the first measurement ( 42 days), and both lots were trans- 
ferred to the same room when at the mean age of II weeks. When measured later, at the mean age of 3 months, the difference in tail length had diminished to 6.7 per cent. The data for this series have nor yet been fully compiled.

\section{SUMMARY OF STATISTICAL DATA}

The more significant facts which may be disentangled from this mass of data may be briefly summarized as follows:

I The tail length (whether absolute or relative) was found to be very much less in the case of those mice which were reared at the lower temperature.

2 This difference was not accompanied by any appreciable difference in the number of vertebra.

3 The foot length was likewise considerably less in all of the cold room lots, though the differences were not so large as in the case of the tail.

4 In two series, at least, the mean ear length was found to be smaller at the lower temperature, but these differences are perhaps to be regarded as "accidental."

5 Body length was not affected with any degree of certainty; while the influence of temperature upon weight, although evident in certain cases, was inconstant, and seemed to depend upon sex.

6 Differences in the average quantity (weight). of hair have been demonstrated for the only series in which the point has been tested. The cold room lot were found to have an average amount of hair which was 11.4 per cent greater absolutely and 13.6 per cent greater relatively (i. e., allowing for the dimensions of the animal) than that of the warm room lot. The number of individuals was, however, small (43) and the variability was high.

7 In another experiment a considerable difference in the average number of hairs per unit of skin area was found among the male mice, the number being greater in the cold room individuals. Here, likewise, the high variability and small number of individuals render any conclusions doubtful.

8 No constant differences in variability were observable between the warm room and the cold room mice.

9 To what extent the modifications cited above have resulted 
from differences in temperature and to what extent from differences in humidity is not certain under the conditions of the experiments.

Io Comparisons of earlier and later measurements upon the same animals show that there is a distinct tendency toward the reduction of these experimentally produced differences during subsequent growth, even when the conditions remain unchanged.

II A diminution in variability within each of the contrasted groups, during the course of growth, was shown to be probable for tail length, at least, and possible in the case of weight.

In order to complete this summary, I will add by way of anticipation:

12 The modifications thus artificially produced are such as have long been known to distinguish northern from southern races of mammals.

\section{GENERAL DISCUSSION OF RESULTS}

In the following comment upon the results of these studies, I shall commence with the last statement in the summary. It is a most significant fact that the experimentally produced differences which have been discussed in the present paper are found to be of just such a nature as are recognized by mammalologists and ornithologists as distinguishing the northern from the southern representatives (individuals or geographical races) of some species. J. A. Allen has repeatedly called attention to the "marked tendency to enlargement of peripheral parts under high temperature or toward the Tropics." 34 Baird and other writers had previously made incidental mention "of the larger size of the bills of southern representatives of northward ranging species" of birds, but Allen offers some detailed examples of this. ${ }^{35}$ He concludes that "an increase in the length of the bill is most frequent in long-billed species, while in short-billed ones the increase is in general size, without material change in its proportions" (p. 23I). A greater curvature sometimes accompanies the increase in length. Like-

\footnotetext{
34 The influence of physical conditions in the genesis of species. Radical Review, I, 1877, pp. 108140. (Reprinted with annotations in Annual Report of the Smithsonian Institution for 1905.)

30 On the Mammals and Winter Birds of East Florida, etc. Bulletin of the Museum of Comparative Zoölogy, vol. 2, I871, pp. 161-450, pl. iv-viii.
} 
wise, "there are well-known instances of an increase in the length of the tail" (meaning the tail feathers). Much more explicit statements are offered regarding mammals, both by Allen and by Coues, though it is stated by the former that the responses to climatic conditions are less evident in this class than among the birds. "In mammals which have the external ear largely developed, as the wolves, foxes, some of the deer, and especially the hares, the larger size of this organ in southern as compared with northern individuals of the same species is often strikingly apparent. . . . . In Lepus callotus ['Lepus texianus and its subspecies' -later note], for example, which ranges from Wyoming southward far into Mexico, the ear is about one-fourth to one-third larger in the southern examples than in the northern. . . . . Among the domestic races of cattle those of the warm temperate and intertropical regions have much larger and longer horns than those of northern countries. . . . . Naturalists have also recorded the existence of larger feet in many of the smaller North American mammalia at the southward than at the northward among individuals of the same species. . . . ." In his monograph on the Muridæ ${ }^{37}$ Coues repeatedly makes similar statements. Referring to a mouse, "Hesperomys leucopus" (now Peromyscus leucopus) (p. 66), he says: "The arctic series averages larger than the United States specimens, and has shorter feet and ears, as well as shorter tail," and he alludes later to "the well-known law of smallness of peripheral parts in Arctic mammals" (p. 83). Comparing the red-backed vole, "Evotomys rutilus gapperi," a more southern "variety," with the species " $E$. rutilus," finds that the vertebral part of the tail is, on the average, about a third of an inch longer in the former, while the foot is 72 hundredths of an inch in length, as compared with 70 hundredths of an inch in the northern form. Relatively, the differences are even

\footnotetext{
3* Op. cit., 1905, Pp. $3^{82-3^{84}}$.

${ }^{37}$ Monographs of North American Rodentia.-Report of the U. S. Geological Survey, vol. xi, I877, pp. I-Iogr.

${ }^{38}$ It is quite possible that two or more distinct species are here referred to. I am not sufficiently familiar with the classsification of the Murida to know the present status of the various species and varieties referred to by Coues. "E. rutilus gapperi" is now regarded as a true species, Evotomys gapperi.
} 
greater, since the northern animals are of larger size. Indeed, the authors cited dwell with equal emphasis upon the larger size of the northern representatives (individuals or varieties) of species, both of birds and mammals, as compared with the southern. Previously, Allen tells us, Baird had "explicitly announced a general law of geographical variation in size; namely a gradual decrease in size in individuals of the same species with the decrease in the latitude and altitude of their birthplaces. ${ }^{30}$ And Allen further affirms that "this is true not only of the individual representatives of each species, but generally the largest species of eacn genus and family are northern. ${ }^{40}$

The foregoing statements were made before the days of exact biometry, and an examination of the tables of measurements offered us shows that in most cases they comprise relatively few individuals and that the material used was not homogeneous, i. e., it includes alcoholic and fresh specimens, as well as dried skins. For this reason most of these tables are not likely to be of very great use to the modern student of variation. In more recent years, a very extensive mass of similar measurements has been gathered by a considerable number of naturalists, but, so far as the writer has been able to discover few if any of these have been subjected to statistical treatment with reference to testing the generalizations of Baird, Allen and Coues. ${ }^{41}$ It would seem overskeptical, however, to reject the emphatic opinions of a number of able naturalists upon these matters, particularly as we have no more satisfactory data at our disposal.

Regarding the pelage, there can be little doubt that this likewise responds directly or indirectly to climatic conditions. "At the northward, in individuals of the same species, the hairs are longer and softer, the under fur more abundant, and the ears and the soles of the feet better clothed. This is not only true of individuals of the same species, but of northern species collectively, as compared with their nearest southern allies."42 Both Coues

\footnotetext{
39 Op, cit., 1871, p. 230.

101905 , p. 378 .

11 I state this on the authority of several of our leading students of mammalian distribution to whom I have appealed for information.

12 Allen, 1905, p. $3^{82}$.
} 
and Allen cited many specific instances of this fact for mice, hares, squirrels and other rodents. Moreover, obvious seasonal changes are to be observed in some species. Speaking of the squirrel, Sciurus hudsonius, var. hudsonius, Allen says: "In summer the soles of the feet are naked, often wholly so to the heel; in winter they are wholly thickly furred, only the tubercles at the base of the toes being naked. The general pelage is also much fuller, longer and softer in winter than in summer." 43

It may well be that the change in the quantity of hair which appears to have been produced in the white mice during the experiments above described was comparable to these seasonal changes, i. e., that the results were purely temporary, and would have disappeared with a cessation of the conditions employed.4 Indeed, since the life of an individual hair is comparatively brief, it would be necessary to effect some permanent change in the physiological activity of the hair follicles, in order that differences such as these should endure. Whether or not these effects are permanent, it has been believed by many that various changes in the character of the hair coat occur in domestic animals as the result of transferrence to an unaccustomed habitat. Darwin, indeed, tells $11 \mathrm{~s}^{45}$ that "Great heat, however, seems to act directly on the fleece; several accounts have been published of the changes which sheep imported from Europe undergo in the West Indies. Dr. Nicholson of Antigua informs me that, after the third generation, the wool disappears from the whole body, except over the loins; and the animal then appears like a goat with a dirty door-mat on its back." And again::48 "It has been asserted on good authority [Isidore Geoffroy St. Hilaire] that horses kept during several years in the deep coal-mines of Belgium become covered with velvety hair, almost like that on the mole." The "classical" Porto Santo rabbit may be cited as another and perhaps more authentic instance of the modification of mammals through changed cli-

\footnotetext{
4s Monographs of N. A. Rodentia, p. 675.

14 It is uncertain, to be sure, in how far the season changes of the hair coat of mammals are direct responses to climatic conditions.

40 Variation of Animals and Plants under Domestication, vol. i, p. 124.

* Op. cit., vol. ii, p. 336.
} 
matic conditions. Here, not only the hair, but other features, were affected.

So far as the present writer is aware, however, no such differences as have formed the principal theme of this paper have been previously brought about by direct experiment or even produced under such circumstances as would warrant one in stating positively that they were the immediate results of external conditions. Lydekker, in the work already referred to, cites a case on the authority of "an American newspaper" (so notoriously infallible in matters scientific!) which would certainly be important if true. It is worthy of mention only because the modifications alleged accord so well, in some respects, with those which have been demonstrated for mice. In order to combat the rats in a cold-storage warehouse at Pittsburgh-so the story runs-cats were introduced. The first of these died. "One cat was finally introduced . . . . which was able to withstand the low temperature. She was a cat of unusually thick fur, and she thrived and grew fat in quarters where the temperature was below $30^{\circ}$. By carfeul nursing, a brood of seven kittens was developed in the warehouse into sturdy thick-furred cats that loved an Icelandic climate. They have been distributed among the other cold-storage warehouses of Pittsburgh, and have created a peculiar breed of cats, adapted to the conditions under which they must exist to find their prey. These cats are short-tailed [italics mine], chubby pussies, with hair as thick and full of under-fur as the wild cats of the Canadian woods. One of the remarkable things about them is the development of their 'feelers.' . . . . In the cold warehouses the feelers grow to a length of five and six inches. This is probably because the light is dim in these places, and all movements must be the result of the feeling sense."

I am informed by Dr. A. E. Ortmann, who has kindly taken the trouble to make some inquiries regarding this story, that he can find no foundation for it whatever. Those who had heard of it at all did not take it seriously. Moreover, as Dr. Ortmann points out, it seems quite unlikely that cats could be forced to live in a cold-storage warehouse unless caged. It has, nevertheless, seemed worth while to cite this account, owing to the prominence given to it by Lydekker. 
Passing to the question of the adaptiveness of these experimentally produced modifications, that of the hair would surely seem to fall within this category. A complementary physiological explanation for the change would doubtless be likewise possible, had we a sufficient knowledge of the various processes concerned. The shrinkage or "drawing in" of the peripheral parts under the influence of a cold climate might also be regarded as adaptive, for the reduction of these thinly clothed surfaces would diminish, at least theoretically, the radiation of heat from the body. Here again a simple physiological explanation is likewise possible. We might either appeal to the effect upon the peripheral circulation (as does Allen) or to the direct influence of temperature upon the protoplasm of the growing parts. In the case of the feet of the mice in the above experiments, the greater activity of the young animals in the warm room, and the greater consequent exercise of the limbs, may possibly have played some part in bringing about the difference.

To what degree the modifications which I have described have been due to temperature and to what degree they have been due to humidity is not clear under the conditions of the experiments. As has been stated, the two have varied inversely. Allen and Coues seem to regard such differences, when presented by mammals in nature, as due chiefly to the temperature factor. Nevertheless, the former writer tells us, speaking of hares, that "there is also a marked tendency to an enlargement of the ears in proportion to the aridity of the habitat. . . . . In this connection, also, attention may be called to the fact that all of the long-eared species of American hares are found exclusively over the most arid portions of the continent. . . . . . ." An it may be added that the color of the pelage of mammals and that of the plumage of birds is well known to vary with the hygrometric conditions. In many species of birds the degree of pigmentation is said to be a function of the mean humidity of the habitat. Tower, indeed, regards the humidity as being much more important than the temperature in the production of color changes in beetles. Until, 
therefore, it is possible to separate these two factors in our experiments, we cannot state with any certainty to what degree each has been operative. A priori, it would seem, perhaps, that the changes in the mice have been such as could more reasonably be attributed to temperature.

The fact that the same sort of differences as those which sometimes obtain in nature between northern and southern species or varieties of animals have been produced by artificial conditions acting within the individual lifetime will be taken by some as evidence that these differences in nature are likewise entirely "ontogenetic" or acquired independently by each individual. Conversely, the neo-Lamarckian will perhaps argue-and with equal right - that here we have evidence that natural varieties and species have resulted from the accumulated effects of external conditions since the reality of such effects has been palpably demonstrated by the present experiments. Neither conclusion is justified by the facts before us. It remains to be settled experimentally (and thus only!) whether or not such modifications are transmissible.

It has already been stated that no constant difference in size between the warm room and cold room individuals has been found to obtain throughout my series. Here, then, the reputed effects of natural climatic conditions have not been paralleled. It is quite possible that the cold was so severe during the early growth stages that some individuals were stunted. Indeed it has been pointed out for the 1907-1908 series that there was considerable mortality amongt the cold room lot in early life. Reference to the frequency polygons in Fig. 2 shows that there are two distinct modes among the cold room individuals; and I have determined that this is equally true of each of the sexes taken separately. The impression conveyed is that there are two pretty distinct groups, one of which was stunted by exposure to the cold, the other being favorably affected, so as even to surpass the warm room lot in size. It must be added, however, that no such effect is manifest in the 1908-1909 series.

One of the most important general conclusions which seem warranted from an analysis of the foregoing results is the principle of the levelling down of experimentally produced inequali- 
ties, even while the conditions which gave rise to them remain in full force. A diminution in initial differences of size has been demonstrated by Minot ${ }^{48}$ in the case of growing guinea-pigs. His findings upon this point are thus summed up: "The study of the individual variations yields two important conclusions: First, that any irregularity in the growth of an individual tends to be followed by an opposite compensating irregularity. Second, the variability diminishes with the age." Thus, "if an individual grows for a period excessively fast, there immediacely follows a period of slower growth, and vice versa, those that remain behind for a time, if they remain in good health, make up the loss (at least in great part if not always completely) soon after. . . . . It is probable that the same is true for man and that therefore the usual and even the severer illnesses of childhood and youth do not greatly affect the ultimate size of the adult." Pearson, ${ }^{40}$ likewise, has shown that the variability both of weight and of stature in man diminishes from infancy to adult life. And indeed it is a matter of common experience that an early handicap in the size or strength of a child is frequently "outgrown," wholly or in part.

The variability which the above-named writers have considered is doubtless in part due to blastogenic differences, in part to somatogenic ones, resulting from fetal or post-natal conditions of nutrition, etc. In my own results, however, the most noteworthy fact is not a reduction in the general variability of my stock, but the diminution of differences whose cause is known to be external-and this while the effective conditions remain unchanged. The foregoing statement applies to the growth of the tail, both of the male and the female mice, between the age of six weeks and the age of $2 \frac{1}{2}$ (or 3 ) months. It likewise holds, with some qualification, for the growth of the tail during the next interval between the measurements, i. e., between $2 \frac{1}{2}$ and 7 months. In the latter case, however, the data are fewer, and the allowance is necessary that about midway during this third period the temperature conditions were equalized

\footnotetext{
${ }^{48}$ Senescence and Rejuvenation. Journal of Physiology, vol. xii, no, 2. 189r, pp. 97-153, pl. ii-iv.

* Proceedings of the Royal Society, lxvi, 1900, p. 23 (cited by Vernon, in "Variation in Animals and Plants").
} 
for the entire lot of animals. The diminution of differences in weight between the contrasted groups of animals is less certain, though it appears tolerably clear in the case of the 1907-1908 females. It will be recalled, however, that the differences in weight were only very doubtfully regarded as results of the temperature conditions.

This tendency toward a reduction of experimentally produced differences in the relative size of parts, should it prove to be general, is of considerable theoretic interest. It adds another to the many well-known examples of a "regulative" tendency in living things. ${ }^{50}$ After the initial shock of change, with its resulting effect in deflecting the organism away from its individual norm, there would seem to be a continuous effort to regain the latter. Here we have a principle which might be said to bear the same relation to individual growth as Galton's "law of filial regression" bears to stem-history, though the analogy may be merely superficial. In either case, however, we have to do with a "reversion to mediocrity." The process in question is directly opposed to that conceived of by Weismann, in his theory of "germinal selection," as occurring among the determinants of the germ-plasm. According to this hypothesis, a given determinant, if once handicapped by unfavorable nutrition, is more and more pushed to the wall by its more fortunate competitors until it may be totally annihilated. The disappearance of useless structures in phylogeny and the frequent orthogenetic trend of evolution is thus explained. If it be objected that this analogy of mine is out of place I can only reply that Weismann's whole conception of a struggle among the determinants of the germ-plasm was derived from what was assumed to occur among the parts of the organism as a whole. Some evidence has been offered above for the existence of a tendency in the growing body quite at variance with the demands of that theory. To many readers, on the other hand, it will doubt-

\footnotetext{
so Vernon's principle that "the permanent effect of environment on the growth of a developing organism diminishes rapidly and regularly from the time of impregnation onwards" (op. cit., p. 199) would account for the failure of these differences to augment with the growth of the organism. But it certainly would not in itself account for the absolutely greater increase shown by the more retarded organs (or organisms) mentioned on p. 137 above.
} 
less seem quite frivolous to attempt any serious refutation of the "germinal selection" hypothesis. In justification, I will but call attention to the fact that this theory is not only treated respectfully but is ably defended in the most recent general treatise on heredity.51

s1 I refer to Thompson's admirable work, Heredity (G. P. Putnam's Sons, Igo8), which should be in the hands of every student of this province. 